\title{
BONE INFECTION: A CLINICAL PRIORITY FOR CLINICIANS, SCIENTISTS AND EDUCATORS
}

\author{
T.F. Moriarty ${ }^{1, *}$, G. Muthukrishnan ${ }^{2}$, J.L. Daiss ${ }^{1}$, C. Xie ${ }^{2}$, K. Nishitani ${ }^{1}$, Y. Morita ${ }^{2}$, H. Awad ${ }^{2}$,
} K.L. de Mesy Bentley², E. Masters², T. Bui², M. Yan², J. Owen³ , B. Mooney², S. Gill², J. Puetzler ${ }^{4}$, J.C. Wenke ${ }^{5}$, M. Morgenstern ${ }^{6}$, W-J. Metsemakers ${ }^{7,10}$, C. Noll ${ }^{8}$, A. Joeris ${ }^{9}$, R.G. Richards ${ }^{1}$, E.M. Schwarz ${ }^{2}$ and S.L. Kates ${ }^{3}$

${ }^{1}$ AO Research Institute Davos, Davos, Switzerland

${ }^{2}$ Center for Musculoskeletal Research, Department of Orthopaedics and Rehabilitation, University of Rochester Medical Center, Rochester, NY, USA

${ }^{3}$ Department of Orthopaedic Surgery, Virginia Commonwealth University, Richmond, VA, USA

${ }^{4}$ Clinic for General and Tumour Orthopaedics, University Hospital Muenster, Muenster, Germany

${ }^{5}$ Orthopaedic Trauma Research Department, U.S. Army Institute of Surgical Research, San Antonio, TX, USA

${ }^{6}$ Center for Musculoskeletal Infections, Department of Orthopaedic and Trauma Surgery, University Hospital Basel, Basel, Switzerland

${ }^{7}$ Department of Trauma Surgery, University Hospitals Leuven, Leuven, Belgium

${ }^{8}$ Institute of Medical Microbiology, University Medical Center Göttingen, Göttingen, Germany

${ }^{9}$ AO Innovation Translation Center, AO Foundation, Dübendorf, Switzerland

${ }^{10}$ KU Leuven - University of Leuven, Department of Development and Regeneration, Leuven, Belgium

\begin{abstract}
Bone infection has received increasing attention in recent years as one of the main outstanding clinical problems in orthopaedic-trauma surgery that has not been successfully addressed. In fact, infection may develop across a spectrum of patient types regardless of the level of perioperative management, including antibiotic prophylaxis. Some of the main unknown factors that may be involved, and the main targets for future intervention, include more accurate and less invasive diagnostic options, more thorough and accurate debridement protocols, and more potent and targeted antimicrobials. The underlying biology dominates the clinical management of bone infections, with features such as biofilm formation, osteolysis and vascularisation being particularly influential. Based on the persistence of this problem, an improved understanding of the basic biology is deemed necessary to enable innovation in the field. Furthermore, from the clinical side, better evidence, documentation and outreach will be required to translate these innovations to the patient. This review presents the findings and progress of the AO Trauma Clinical Priority Program on the topic of bone infection.
\end{abstract}

Keywords: Fracture-related infection, Staphylococcus aureus, biofilm, osteomyelitis, canaliculi, hydrogel.

*Address for correspondence: T. Fintan Moriarty, AO Research Institute Davos, Clavadelerstrasse 8, 7270 Davos Platz, Switzerland.

Telephone number: +41 814142397 Email: fintan.moriarty@aofoundation.org

Copyright policy: This article is distributed in accordance with Creative Commons Attribution Licence (http://creativecommons.org/licenses/by-sa/4.0/).

\begin{tabular}{|c|c|c|c|}
\hline & List of Abbreviations & CHIPS & $\begin{array}{l}\text { chemotaxis inhibitory protein of } \\
\text { S.aureus }\end{array}$ \\
\hline AIGEC & Anti-Infection Global Expert & CoNS & coagulase-negative staphylococci \\
\hline ALBC & $\begin{array}{l}\text { Committee } \\
\text { antibiotic-loaded bone cement }\end{array}$ & CORS & $\begin{array}{l}\text { Canadian Operational Research } \\
\text { Society }\end{array}$ \\
\hline Amd & amidase & CPP & Clinical Priority Program \\
\hline ASC & antibody-secreting cell & CPS & calcium phosphate scaffolds \\
\hline AUC & area under the curve & CRP & C-reactive protein \\
\hline BMI & body mass index & DAIR & debridement, antibiotic treatment \\
\hline $\mathrm{CaP}$ & calcium phosphate & & and implant retention \\
\hline CFU & colony-forming unit & DFI & diabetic foot infections \\
\hline
\end{tabular}




\begin{tabular}{|c|c|}
\hline EBJIS & $\begin{array}{l}\text { European Bone and Joint Infection } \\
\text { Society }\end{array}$ \\
\hline ESR & erythrocyte sedimentation rate \\
\hline ESWT & extracorporeal shockwave therapy \\
\hline FDA & Food and Drug Administration \\
\hline FRI & fracture-related infection \\
\hline FST & foot salvage antimicrobial therapy \\
\hline G-CSF & $\begin{array}{l}\text { granulocyte-colony stimulating } \\
\text { factor }\end{array}$ \\
\hline Gmd & glucosaminidase \\
\hline ICM & international consensus meetings \\
\hline IL & interleukin \\
\hline IsdB & $\begin{array}{l}\text { iron-regulated surface determinant } \\
\text { protein B }\end{array}$ \\
\hline $\begin{array}{l}\mathrm{KC} \\
\mathrm{mAb}\end{array}$ & $\begin{array}{l}\text { keratinocyte chemoattractant } \\
\text { monoclonal antibodies }\end{array}$ \\
\hline MALDI-TOF & $\begin{array}{l}\text { matrix-assisted laser desorption/ } \\
\text { ionisation time-of-flight MS }\end{array}$ \\
\hline MBEC & $\begin{array}{l}\text { minimum biofilm eradication } \\
\text { concentration }\end{array}$ \\
\hline MENSA & $\begin{array}{l}\text { medium enriched for newly } \\
\text { synthesised anti-S. aureus antibodies }\end{array}$ \\
\hline MIC & minimum inhibitory concentration \\
\hline MRSA & methicillin-resistant S. aureus \\
\hline MS & mass spectrometry \\
\hline MSIS & MusculoSkeletal Infection Society \\
\hline NOD-SCID & $\begin{array}{l}\text { nonobese diabetic/severe combined } \\
\text { immunodeficiency }\end{array}$ \\
\hline NSG & NOD-SCID gamma \\
\hline OLCN & oo-canalicular networ \\
\hline ORS & Orthopaedic Research Society \\
\hline OTA & Orthopaedic Trauma Association \\
\hline PJI & periprosthetic joint infection \\
\hline PLGA & poly(lactic-co-glycolic acid) \\
\hline PMMA & polymethyl methacrylate \\
\hline S. aureus & Staphylococcus aureus \\
\hline S. epidermidis & Staphylococcus epidermidis \\
\hline SEM & scanning electron microscopy \\
\hline SSI & surgical site infection \\
\hline T2D & type 2 diabetes \\
\hline TEM & $\begin{array}{l}\text { transmission electron } \\
\text { microscopy }\end{array}$ \\
\hline & white blood cell \\
\hline
\end{tabular}

\section{Introduction}

Bone infection comprises a range of related, yet significantly distinct clinical fields including FRI, PJI, septic arthritis and diabetic foot osteomyelitis, amongst others. The burden of bone infection is often associated with high-risk populations - such as open fractures, immunocompromised patients and patients undergoing revision surgery. However, a bone infection may also occur in patients without any remarkable comorbidity or risk factor and is a potential outcome for any patient receiving an orthopaedic device. Regardless of the underlying reasons, bone infection can have significant consequences for the patient and can be a challenging complication for the multidisciplinary team of microbiologists, infectiousdisease physicians and orthopaedic-trauma surgeons involved in caring for such a patient (Fig. 1). In recent years, consensus opinions derived from international expert panels have emerged to provide guidance on best practice in prevention, treatment and diagnosis, and advance from the previous eminence-based practice. This has been a welcome development for the field that promises to provide a framework for future prospective studies and internationally accepted evidence-based treatments in the coming years.

The persistence of bone infections, despite best practice, suggests that current concepts and interventions can be further improved. Some of the innovations that have relatively recently reached the clinic include biomaterials such as antibiotic-loaded synthetic bone substitutes (Pesch et al., 2020), implant coatings (Metsemakers et al., 2015), mechanical innovations such as the reamer irrigator aspirator (Tosounidis et al., 2016), diagnostic innovations such as the alpha defensin assay (Marson et al., 2018) and a small number of clinical trials on immunisation against $S$. aureus that remain either unpublished or without confirmed efficacy (Proctor, 2015). The penetration of some of these innovations in the clinic, and their impact, are yet to be determined, although significant further advances will certainly be required in the coming decades. Amongst the few to have reached the clinic, there is the alpha defensin test, which has been applied in a lateral flow format and used in synovial fluid for the detection of PJIs. To date, results suggest it has value, although it may not be superior to existing measures such as WBC and neutrophil count (Ivy et al., 2021).

Targets for further research should include i) the inability to develop an effective immunisation strategy against the most common pathogen in bone infection, S. aureus; ii) antimicrobial resistance, which may render even current standards such as systemic and local antibiotic therapy increasingly ineffective; iii) the inability to target biofilm-growing bacteria or bacteria residing within the osteocytelacuno canalicular system. Whether these issues will eventually be addressed by improved diagnostics or surgical resection, e.g. debridement tools more potent and fit-for purpose antimicrobials or a combination thereof, remains to be seen. Importantly, translation to the clinic will require a balance between responsible use of antibiotics and convincing clinical data on potential to improve patient care. Despite the numerous options currently available in the clinic, the patients' needs are not fully met. The consequence is the continued and widespread use of "home-made solutions" using antibiotics in an off-label manner such as the application of antibiotic powders directly to the wound, irrigation with antibiotic solutions and self-fabricated antibiotic delivering spacers that are the best available option, though far from ideal and frequently based on a limited amount of scientific evidence. 
The combined potential of basic science, clinical science and industry seems, nevertheless, well placed to make progress in the coming decades. The present review aims to provide an overview of new areas of research identified by expert consensus committees that will be required to impact patient care. Furthermore, the AO Trauma CPP on bone infection was convened to tackle this clinical need and the scientific outputs of this surgeon-driven, science-based consortium are also described.

\section{New concerns from ICMs}

In the $20^{\text {th }}$ century, clinical treatment protocols for infection in orthopaedics were established by innovators responding to urgent needs and many of these protocols became "standard of care" without level 1 evidence to support them. While most of these protocols have proven their worth from clinical experience, the new era of value-based healthcare policies that demands evidence-based medicine has changed the cost-effectiveness of some, which have been the focus of transformative ICMs (Schwarz et al., 2020; Schwarz et al., 2019). At the commencement of the AO Trauma CPP on bone infection, one of the most controversial issues was the upper limit of BMI threshold for elective surgery, which provoked strong arguments between delegates to the point that the question was removed without an official vote at the 2013 ICM. However, this stimulated high level peer-reviewed research that facilitated "unanimous" agreement at the 2018 ICM, which voted that there is "strong" and "consensus" evidence that "a substantially increased risk is noticed in patients with a BMI $>40 \mathrm{~kg} / \mathrm{m}^{2}$ and the risks of surgery must be carefully weighed against its benefits in these patients" (Schwarz et al., 2019). The 2018 ICM also revealed other major points of contention, the main one being the absence of a functional definition of "acute" and "chronic" infection with which to guide clinical decision (i.e. retention or removal of hardware), which could not be resolved by the general assembly or the biofilm workgroup (Saeed et al., 2019). In support of modifying guidelines to define "acute" versus "chronic" infection based on histopathology features (neutrophils vs. macrophages and plasma cells respectively), the AO Trauma CPP published clinical data demonstrating that these features can co-exist in the same bone biopsy (Masters et al., 2019b). The AO Trauma CPP also responded to several of the 38 "high-priority" research questions identified by the 2018 ICM (Schwarz et al., 2019), including the efficacy of ALBC. A focussed ICM was held on this specific topic, highlighting several major concerns with the way ALBC is used (Schwarz et al., 2020). The first is that there is no level 1 evidence demonstrating its proven efficacy to prevent or treat bone infections. The second is that the classical MIC used in an in vitro assay to evaluate and compare antibiotics has little if any value for clinical translation of novel therapies for established biofilm infections or those treated locally. Moreover, new assays to evaluate the MBEC that account for bacteria killing time (Castaneda et al., 2016), biofilm age (Holmberg and Rasmussen, 2016) and host factors such as plasma and haeme (Cardile et al., 2014) and can be translated to the clinical microbiology laboratory are needed. The third is that commonly used antibiotics in ALBC (e.g. gentamicin) can potentially lead to resistant

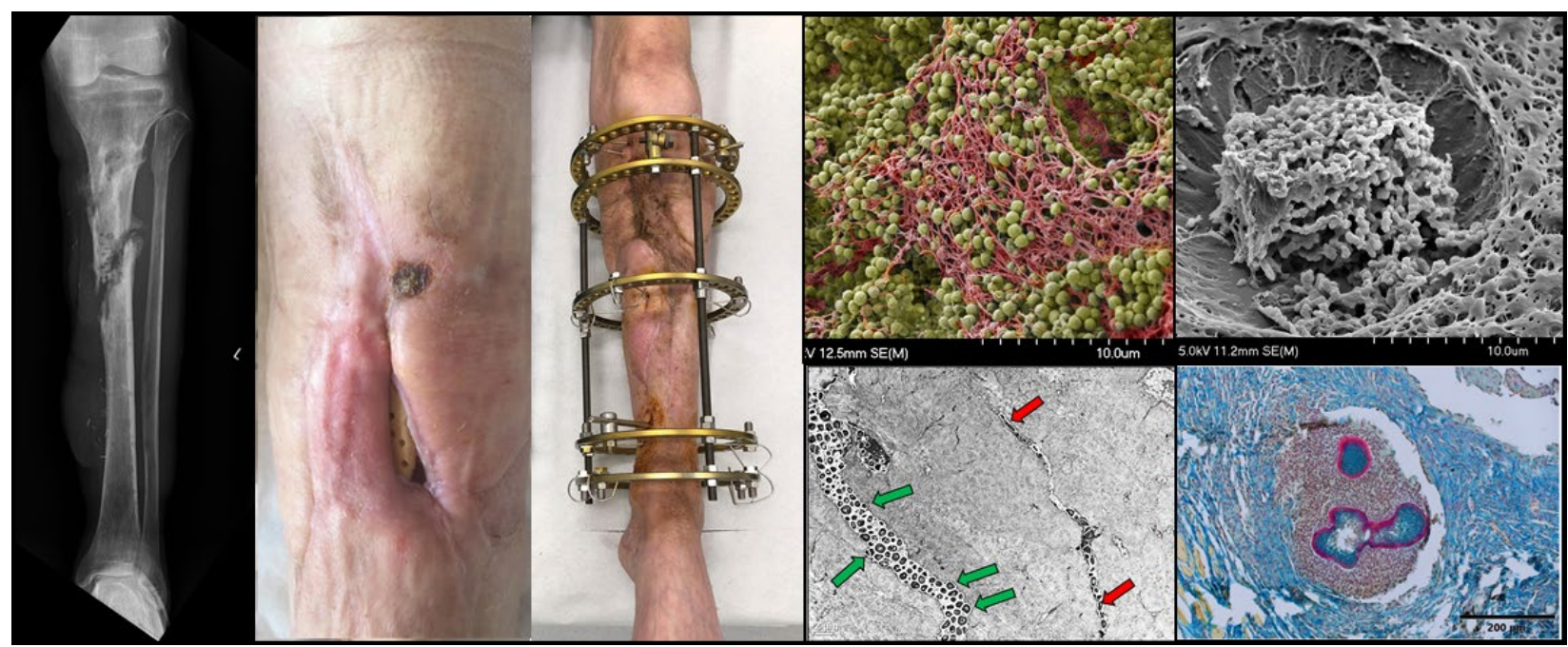

Fig. 1. Key phenomena in bone infection from the clinical and basic science perspective. Left-hand side, macroscopical images of an FRI. From left, radiographic image of a patient with an FRI revealing healing complications and periosteal reaction. Image reveals simultaneous failure of soft-tissues healing, revealing the pale avital bone through the unhealed soft tissue wound. Fixation of the fracture after treatment may require invasive procedures and prolonged presence of fixation devices, such as a ring fixator. Right handside, microscopical images of the basic biological features involved in bone infection as revealed by in vitro and laboratory animal studies. Upper left, an in vitro grown biofilm of S. aureus, including extracellular matrix and fibrin (red). Upper right, Cutibacterium acnes present in an osteocyte lacuna in a rabbit; lower left, $S$. aureus propagating through the OLCN in an infected bone; lower right, a staphylococcal abscess community in the bone marrow of an infected mouse. 
isolates emerging (Neut et al., 2003). These concerns serve as prime targets for future interventions.

\section{Multidisciplinary approaches to address the clinical problem of bone infection}

It seems unlikely that significant advances can be made without interdisciplinary collaboration across scientific, clinical and industrial stakeholders. From a basic-science perspective, improved understanding of the basic biology of bone infection will absolutely be needed to identify new targets that can prevent and treat bone infections. From a clinical perspective, the development of bone infection registries, collecting real-world data on a large scale as well as high-quality clinical studies to separate the interventions that have efficacy from those that do not are key to widespread adoption of new technologies. The AO Trauma CPP was established in a ground-up approach, whereby an obvious clinical problem required input from an interdisciplinary consortium. The structure of the consortium included careful consideration of the basic-science problems as well as clinical evidence and patient materials needed to provide a better understanding of the clinical problem. Finally, the structure included educational and outreach aspects to ensure best practices were presented to the medical and scientific community and ensure that the benefits of scientific advances could be moved from theory into practice. The following sections present the scientific highlights of the programme as well as educational aspects used to further improve current best practice.

\section{Host-pathogen interactions in bone infection}

\section{Invasion of bone canaliculi by $S$. aureus}

Recently, the understanding of the pathophysiology of bone infections has evolved arising from TEM imaging studies in infected bone of both human and murine origin. Historically, S. aureus was defined as $1 \mu \mathrm{m}$-diameter cocci incapable of motility. However, TEM studies have shown deformed and propagating rod-shaped bacteria, ranging in diameter between 0.2 to $0.8 \mu \mathrm{m}$, occupying the sub- $\mu \mathrm{m}$ OLCN in live cortical bone (Fig. 2) (de Mesy Bentley et al., 2018; de Mesy Bentley et al., 2017). Initiation of OLCN invasion is accomplished through asymmetric binary fission of daughter cells, proliferating at the leading edge while utilising demineralised collagen as a nutrient source. Through careful observation and serial sectioning, this deformed elongated shape was confirmed in both murine (de Mesy Bentley et al., 2017) and human (de Mesy Bentley et al., 2018) bone, proving not to be an artefact of sectioning, and was recently also reported by others (Zoller et al., 2020).

Further studies have shown that $S$. aureus also infects living osteocytes and forms small colony variants in this niche in vitro; moreover, infection of osteocytes has also been shown in human patients (Yang et al., 2018). As each osteocyte has approximately 40-50 canaliculi (Beno et al., 2006; Tiede-Lewis et al., 2017), these cells may effectively serve as OLCN "hubs" for continued bacterial invasion to neighbouring and distant osteocytes within bone tissue and may be a key factor in infection persistence.

The authors' hypothesis was that S. aureus invasion of the OLCN is driven by a novel genetic mechanism that enables bacterial cell deformation and propagation through canaliculi. To determine $S$. aureus genes involved in this novel phenotype, an in vitro platform was created featuring a nanoporous membrane to mimic the size and geometry of canalicular openings. Using this platform, $S$. aureus strains with mutations in genes hypothesised to be involved in OLCN invasion were screened for their ability to propagate through nanopores (Masters et al., 2019a). This study identified the $S$. aureus gene $p b p 4$, encoding an uncanonical cell-wall transpeptidase (da Costa et al., 2018), as necessary for $S$. aureus deformation and propagation through $0.5 \mu \mathrm{m}$ pores in vitro. Subsequent in vivo studies of implant-associated bone infection have proved that $p b p 4$ deletion results in decreased peri-implant bone loss due to decreased osteoclast activation as well as complete loss of OLCN invasion (Masters et al., 2020). While continued research is required to completely describe the mechanism of $S$. aureus OLCN invasion, genes identified by Masters et al. (2020) represent possible targets for the development of novel antimicrobials to treat infections.

\section{Fracture stability and infection}

One of the unique features of FRIs that is not present in PJI, for example, is the role of biomechanical stability and fracture healing. Fracture healing has often been described using the "diamond concept", which includes osteogenic cells, an osteoconductive scaffold, growth factors and biomechanical stability (Giannoudis et al., 2007). Immune responses have more recently emerged as an additional component of fracture healing, whilst simultaneously being crucial for defence against pathogens. Recently, Sabaté-Brescó et al. (2017b) have shown that a lack of biomechanical stability leads to a delay in clearance of $S$. epidermidis from bone osteotomies in mice. This supports, in general terms, the long-standing teaching that stability is required to reduce infection risk (Foster et al., 2020c). This may be due to improved bone healing and protection of vascularisation under optimal stability but also inflammation and vascular damage under conditions of instability. Data suggested that fracture instability leads to a local increase in inflammatory cytokines such as G-CSF, KC and IL-6 and that this is exacerbated in the presence of S. epidermidis (Sabaté-Brescó et al., 2021). S. aureus infections result in a much more severe inflammatory response, associated with increased secretion of pro-inflammatory cytokines and a rapid loss of stability, once again highlighting the significant differences in pathogenesis between 


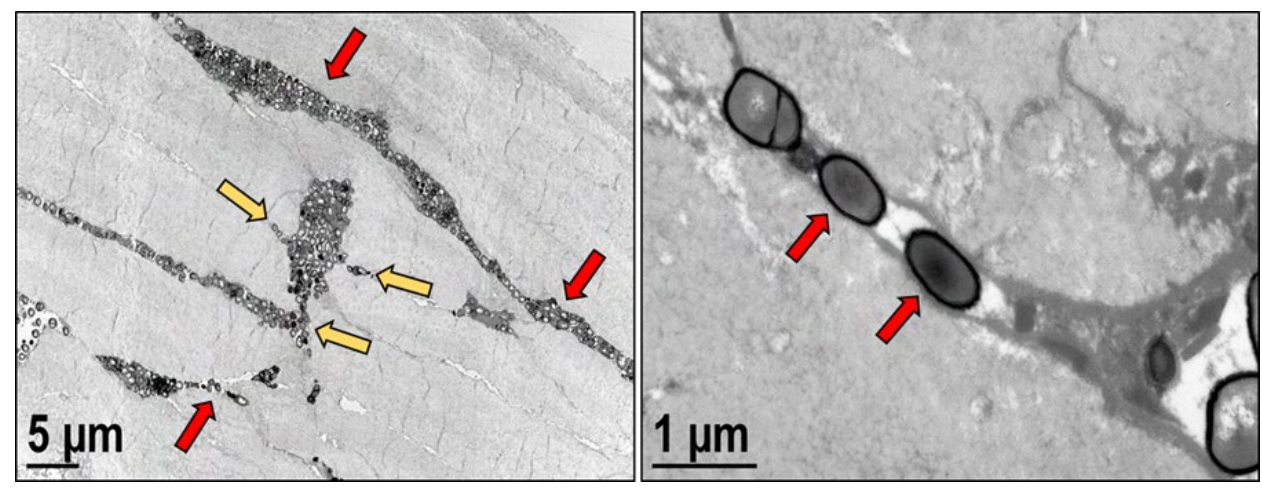

Fig. 2. TEM imaging of S. aureus invasion into the OLCN. Left: an osteocyte (yellow arrows) has been killed by S. aureus that have invaded into its lacunar space. Note, deformed bacteria are infiltrating into canaliculi emanating from the lacunar space (tips of yellow arrows). The OLCN connection between osteocytes facilitates continued invasion into neighbouring and distant osteocytes (red arrows) $(\times 3,500)$. Right: a TEM image displaying $S$. aureus cocci deformation to accommodate the submicron space of an osteocyte's canaliculus $(\times 30,000)$.

S. epidermidis and S. aureus (Sabaté-Brescó et al., 2017a). This study offers an obvious link between surgical practice, stabilisation options and FRI risk and provides a mechanistic insight into long-standing clinical teaching based on clinical experience.

\section{Impact of obesity and T2D on implant-associated osteomyelitis}

Among other risks, obesity/T2D increase susceptibility to bone infections following orthopaedic surgery (Dowsey and Choong, 2009; Jamsen et al., 2012; Wu et al., 2014), not including ulcerative soft tissue infections that spread to underlying bone. Earlier data indicates that persistent osteomyelitis occurs in cases of obesity/ T2D due to two concurrent mechanisms: 1) response of $S$. aureus to the diabetic-host microenvironment; 2) impairment of the immune responses due to the chronic inflammation (Farnsworth et al., 2017). S. aureus upregulates fibrinogen adhesion proteins to exploit the increased fibrinogen levels circulating in the obese, diabetic host to initiate and propagate fibrin-encapsulating abscesses, which facilitate evasion of immune cells (Bembde, 2012; Farnsworth et al., 2017; Kannel et al., 1990). Obese/T2D hosts have also been historically characterised to have weakened neutrophil functions including adhesion, migration and phagocytosis, as shown in ex vivo experiments (Alba-Loureiro et al., 2006; Delamaire et al., 1997; Gallacher et al., 1995; Kuwabara et al., 2018). However, in vivo data from obese/T2D host foot ulcer and implant-associated mouse models suggest that innate immune cells are highly recruited to the site of infection despite diminished clearance of S. aureus (Farnsworth et al., 2018a; Farnsworth et al., 2018b). Continued recruitment of innate immune cells to infected bone during chronic infection suggests sustained inflammation that could inhibit normal bone repair processes, as indicated by increased periosteal reactive bone formation and enhanced osteolysis in obese/T2D hosts (Farnsworth et al., 2018b). Functional deficits in both innate and adaptive immunity likely contribute to increased infection severity and susceptibility. Decreased T cell and B cell activation is associated with reduced production of $S$. aureus-specific IgG (Farnsworth et al., 2018a; Farnsworth et al., 2015). Immuneimpairing hyperinflammation in the obese/T2D host is also linked to other complications of this disease, including liver dysfunction, islet inflammation and gut dysbiosis, which appear to be primarily mediated by obesity (Belkaid and Hand, 2014; Lumeng and Saltiel, 2011; Thingholm et al., 2019). Thus, targeting the causes of inflammation in obese/T2D patients, such as the well-recognised gut dysbiosis, opens promising new avenues for decreasing susceptibility to the more severe implant-associated osteomyelitis and other complications in this disease population.

\section{Host immunity against $S$. aureus: protective $v s$. susceptible immune proteomes}

In a cohort of patients with bone infection, IsdB, a haeme-iron scavenging surface protein, was identified as the most immunodominant antigen during $S$. aureus bone infection (Nishitani et al., 2015a). Remarkably, patients with high titres of circulating antibodies against IsdB were more likely to die from infection (Nishitani et al., 2015a), indicating their role as susceptibility enhancement antibodies. That result was consistent with the failure of the phase IIB/III clinical trial of an IsdB active vaccine (Merck's V710), which was associated with an increased mortality rate due to sepsis in patients with SSI (Fowler et al., 2013). Preclinically, a trojanhorse macrophage theory showed that anti-IsdB antibodies can facilitate $S$. aureus internalisation and survival in macrophages in vitro and mediate S. aureus dissemination to distal organs in vivo, indicating that $S$. aureus invades host macrophage using anti-IsdB antibodies and proliferates and disseminates in an immune-privileged environment (Nishitani et al., 2020). In sharp contrast to anti-IsdB antibodies, antibodies against the Gmd protein 
subunit of $S$. aureus autolysin were identified as protective antibodies utilising murine-osteomyelitis models (Varrone et al., 2014; Yokogawa et al., 2018). In a clinical study within the AO Trauma CPP Bone Infection Registry, it was found that only $6.7 \%$ of osteomyelitis patients had high levels of circulating anti-Gmd antibodies and these high levels of antiGmd were associated with a nearly 3-fold increase in infection-control odds, suggesting that anti-Gmd passive immunisation therapy for osteomyelitis might be beneficial and a potential target for future intervention (Kates et al., 2020b).
Development of a passive immunisation for $S$. aureus osteomyelitis

While vaccines are the most cost-effective intervention for infectious diseases, to date, all efforts to develop an immunisation against $S$. aureus have failed for various reasons (Proctor, 2015). The main challenges include lack of knowledge of protective versus antibody-dependent bacterial infection enhancement and the great variability in patient-specific immune responses, which are biased by prior exposures to this commensal (Muthukrishnan et al., 2019a; Ricciardi et al., 2018; Ricciardi et al., 2020b). With this knowledge, a

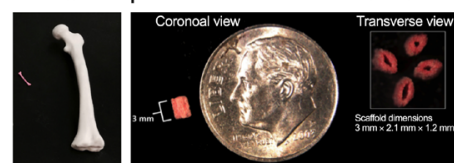

Drug/antibiotic loading

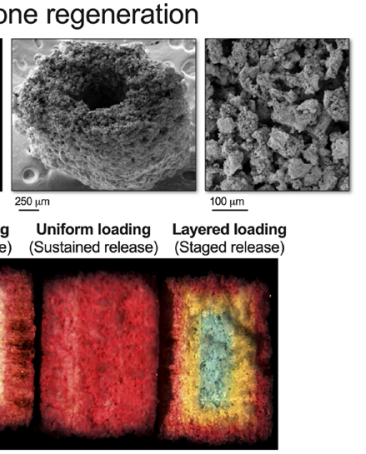

C

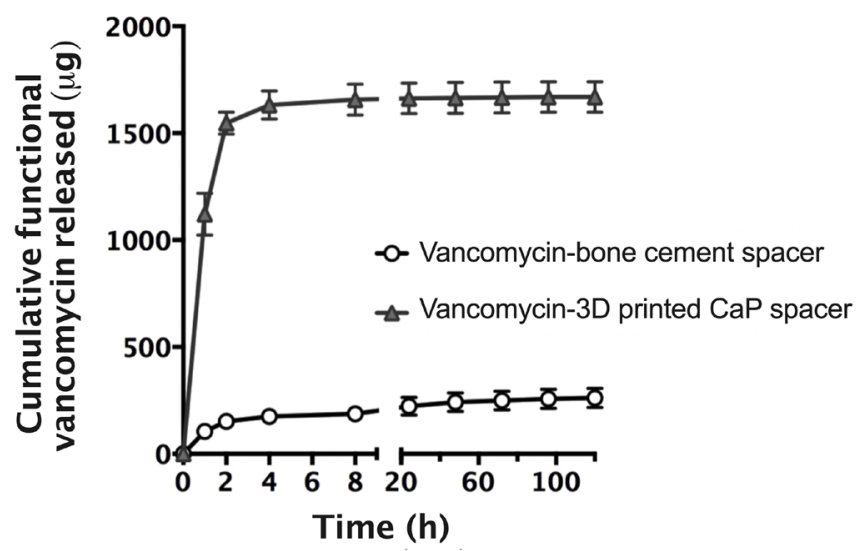

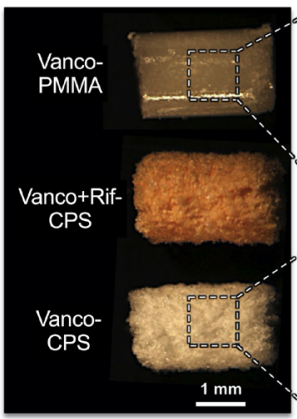
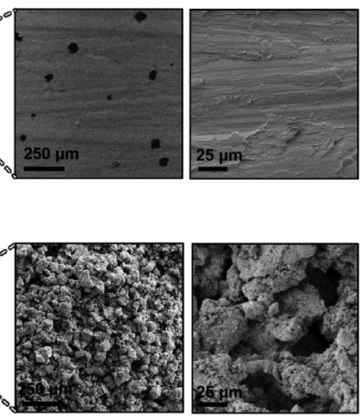

d

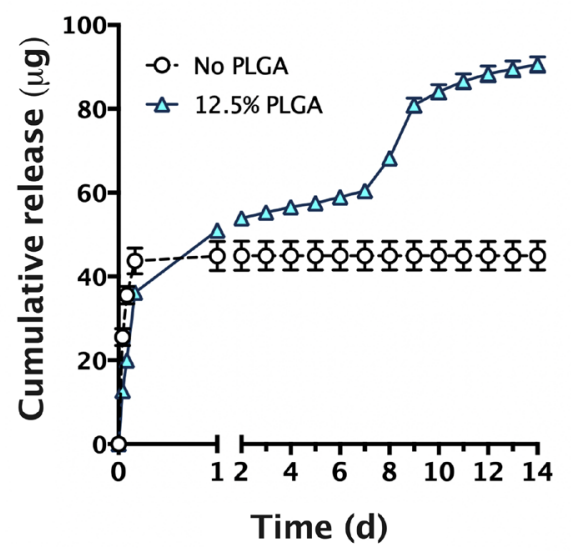

e

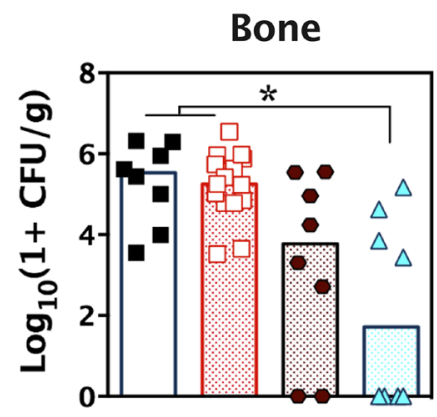

Muscle and soft tissue

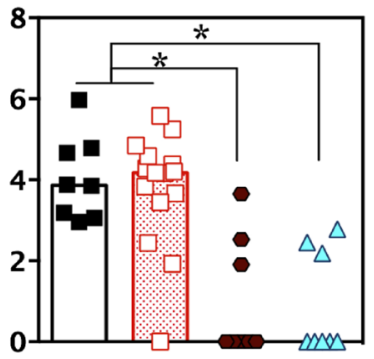

Antibiotic spacer

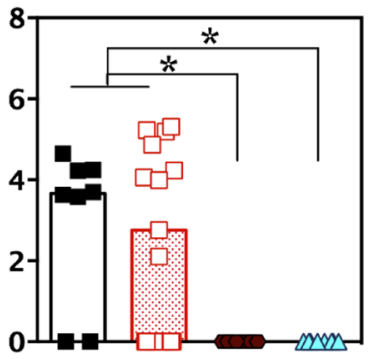

Fig. 3. 3D-printed CaP scaffolds. (a) CaP scaffolds for bone regeneration and infection eradication can be scaled from human to murine anatomy. SEM images of the CaP surface shows porous structure for efficient cell attachment. CaP scaffolds can be loaded with antibiotics specifically printed into different regions of the scaffold, indicated by different colours. (b) Differences in the surface morphology and porosity between 3D-printed CPS and PMMA spacers are shown by SEM images of various antibiotic-loaded scaffolds. (c,d) Antibiotic release of vancomycin-loaded spacers. (e) Bacterial colonisation, measured by end-point CFU assay, was reduced by low-dose local antibiotic delivery using 3D-printed CPS. 
a preclinical research program was commenced to identify protective antigens in a murine model of implant-associated osteomyelitis (Li et al., 2008; Nishitani et al., 2015b) and an international registry of orthopaedic patients with culture confirmed S. aureus bone infections was developed to correlate patientspecific immune responses with clinical outcomes (Kates et al., 2020a; Morgenstern et al., 2020b). Independently, these research programs derived the same conclusions that immunity against the autolysin antigens (Amd and Gmd) is protective, while antibodies against the iron surface determinant (Isd) proteins are potentially pathogenic through induction of trojan-horse macrophages and sepsis following SSI (Masters et al., 2019b; Nishitani et al., 2020). Preclinically, passive immunisation with anti-Gmd $\mathrm{mAb}$ protects mice from MRSA infections (Varrone et al., 2014) and prevents reinfection following a onestage revision surgery (Yokogawa et al., 2018). Also, these research programmes demonstrated the safety of a clinically relevant intravenous infusion of antiGmd $\mathrm{mAb}$ in sheep and estimated the circulating half-life to be $23.7 \mathrm{~d}$. Using the patients' sera from the AO Trauma CPP Bone Infection Registry, Lee et al. (2020) demonstrated that endogenous anti-Gmd antibody levels in sera of osteomyelitis patients ranges from $<1 \mathrm{ng} / \mathrm{mL}$ to $300 \mu \mathrm{g} / \mathrm{mL}$, with a mean concentration of $21.7 \mu \mathrm{g} / \mathrm{mL}$, and estimated its circulating half-life to be $120.4 \mathrm{~d}$. Thus, an anti-Gmd $\mathrm{mAb}$ passive immunisation to treat $S$. aureus bone infection, akin to bezlotoxumab (Zinplava ${ }^{\mathrm{TM}}$ ) passive immunisation to prevent recurrent Clostridioides difficile infection (Prabhu et al., 2018; Wilcox et al., 2017), is feasible. Additionally, implementing this approach rather than pursue an active vaccine would likely circumvent the problems of host immune variability, immunosuppression and post-infection phenotypic adaptation by the pathogen. However, this will require a companion diagnostic to identify patients who do not have endogenous neutralising antibodies and would be expected to benefit from this therapy. Furthermore, potential issues in translating experimental results from murine to human populations remains a challenge.

\section{Humanised mice}

The failure to have effective anti-S. aureus immunotherapies can partially be attributed to overreliance on murine model systems to study human immunology. Often, the knowledge acquired using mice models does not necessarily translate into useful vaccine candidates in humans. A case in point is the murine preclinical data of an IsdB-based immunogenic vaccine candidate that demonstrated reduced infection lethality and protection against bacteraemia in mice (Brown et al., 2009; Kim et al., 2010; Kuklin et al., 2006; Torres et al., 2006). Unfortunately, an active vaccination clinical trial based on these preclinical studies involving 8,000 patients failed to protect against $S$. aureus bacteraemia (Fowler et al., 2013).

While being a common commensal, $S$. aureus is an acknowledged human pathogen with numerous virulence factors and bicomponent toxins with a high degree of tropism to receptors expressed on human leukocytes (Alonzo and Torres, 2013; Alonzo and Torres, 2014). Therefore, S. aureus does not necessarily exhibit its typical phenotype in murine $S$. aureus infections. A small rodent model with human specificity, correct receptor targets and relevant immune cells will be more suitable for studying a human-adapted pathogen such as S. aureus.

Humanised mice generated by engrafting human immune cells to immunodeficient NODSCID IL2R $\gamma$ null (NSG) mice (Ishikawa et al., 2005; Lan et al., 2006; Shultz et al., 2005) are an attractive model to study $S$. aureus pathogenesis during bone infections. As part of the AO Trauma CPP research program priority areas, the utility of these humanised mice to study $S$. aureus bone infections was recently evaluated and it was examined if they elicited human immune responses due to $S$. aureus osteomyelitis (Muthukrishnan et al., 2021). Interestingly, humanised mice suffered exacerbated osteomyelitis and engrafted human T cell responses correlated with infection severity in these humanised mice (Muthukrishnan et al., 2021). A human-relevant preclinical small animal model would be beneficial to 1 ) evaluate active and passive $S$. aureus vaccine candidates and 2) compare inter-individual responses to infection based on donor-specific factors.

\section{"The race for the surface" might be a sprint}

The "race for the surface" concept has been the prevailing explanation for understanding the fate of implants where there is competition between bacterial colonisation and host-cell integration and protection (Gristina, 1987; Gristina et al., 1988). If microbes reach the surface first, they will attach, replicate, form a biofilm and cause a recalcitrant infection. Conversely, host-cell integration occurring before bacteria colonisation will result in lower chances of infection and improved implant survival. A common anti-infection approach is to protect the implants against bacterial colonisation by an active (releasing antimicrobials) or passive coating but the timeline for the host to be able to fend for itself is still unknown. Therefore, the optimum antimicrobial release kinetics and release duration are not known and a common approach is to have an extended release, often for a month or more. Recently, a preclinical implant infection model was developed where the device implantation was uncoupled from bacterial challenge to provide an understanding of the role time plays in the cellular events that are required to prevent implant infection (Shiels et al., 2020). In this bilateral intramedullary nail rat model, $S$. aureus was injected into the tail vein either immediately after or 1, 3 and $7 \mathrm{~d}$ following implant placement. 2 weeks following inoculation, implants and tissues were harvested for 
bacterial quantification. As time between implant placement and bacterial challenge increased, infection rate and bioburden decreased. Almost all implants had measurable bioburden when challenged at day 1 but only two implants had recoverable bacteria when inoculated $7 \mathrm{~d}$ after implant placement. Additional animals were not inoculated but euthanised at 1 , 3 or $7 \mathrm{~d}$ and the host cells adhered to the implant were identified. This protection against infection corresponded to a shift in host cell population surrounding the implant. Initially, cells present were primarily non-differentiated stem cells, such as bone marrow mesenchymal stem cells or immature haematopoietic cells. At day 7, there was a mature monocyte/macrophage population. Importantly, it appears that the initial cell population differentiated into the immune cells and the timeline for this appears to be fairly conserved across species. Studies in different anatomic locations, species and health status (comorbidities such as diabetes, advanced age, trauma, etc.) along with implant coating and antimicrobial release would help to understand further the timeline where the body can protect the implant and surrounding tissue against infections. Taken together, it appears that therapies and strategies may only need to protect implants against bacterial colonisation for approximately a week.

\section{a Perioperative administration of antibiotic prophylaxis}
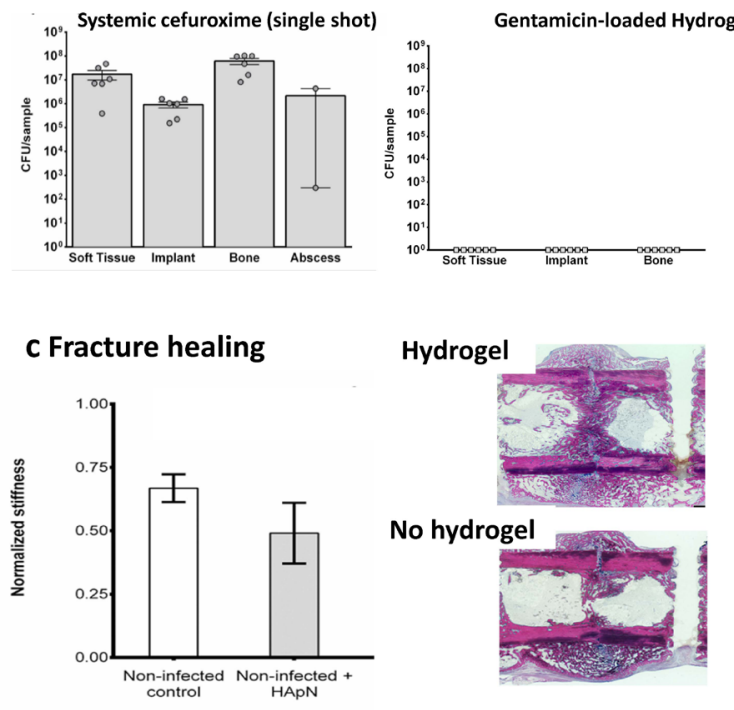

\section{Preclinical studies into prophylaxis and treatment}

3D-printed antimicrobial-loaded CaP

When a bone allograft or an orthopaedic device is infected, thorough debridement of the infected bone and soft tissue is standard of care and often a temporary hand-moulded ALBC spacer is also implanted to support treatment. ALBCs are commonly used despite lack of evidence for efficient drug delivery. Published data show that ALBC burst release about 5 to $15 \%$ of the incorporated drugs within the first $24 \mathrm{~h}$, with significantly less drug release in the following days followed by a prolonged tail of likely sub-inhibitory concentrations (Moojen et al., 2008). Furthermore, ALBC requires revision surgery to first debride the infected bone and treat the infection, by temporarily installing the spacer, and then to remove it and treat a possible bone defect. Therefore, next generation biomaterial spacers are required that enable sustained and controlled delivery of the antibiotics over an extended period in singlestage procedures for infection management and bone repair. To meet these criteria, several groups (Inzana et al., 2016; Trombetta et al., 2017) have developed 3D-printing strategies to design bioactive ceramic spacers that can function as antibiotic-eluting devices and, concurrently, as biodegradable, osteo-inductive

\section{b "Pre-hospital" administration of antibiotic prophylaxis}
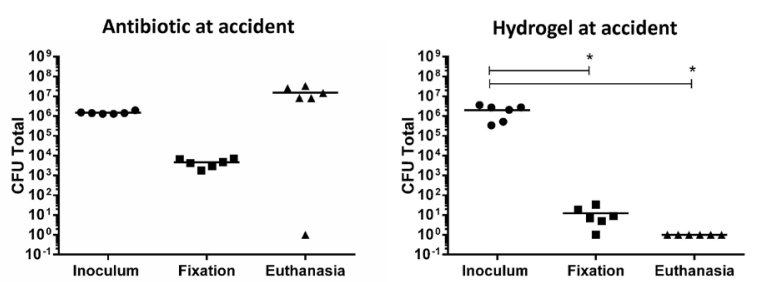

d In vivo local tissue concentrations

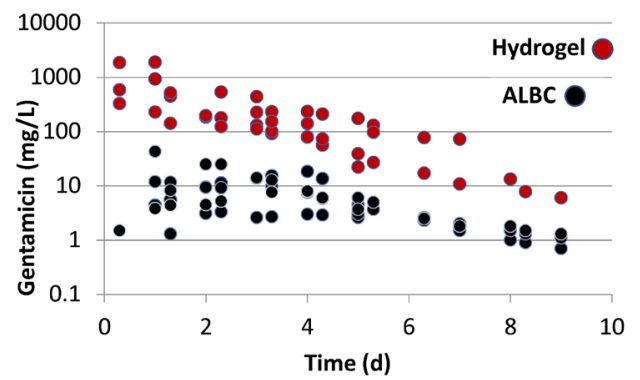

Fig. 4. Preclinical efficacy of an antibiotic-loaded thermo-responsive hyaluronic acid hydrogel. (a) In a rabbit humeral osteotomy and plate fixation model, the antibiotic loaded hydrogel achieved complete protection of all animals, whilst systemic delivery of a single shot of cefuroxime could not prevent infection in any. (b) The hydrogel formulation may also be applicable by first responders and, in this study, antibiotic therapy was given in a modified animal-model whereby the initial wound and inoculation occurred $4 \mathrm{~h}$ prior to fixation. In this model, the antibiotic-loaded hydrogel could completely prevent infection when given at the time of accident and washed-out during fixation surgery, whilst systemic antibiotics once again failed to prevent infection. (c) Fracture healing in the presence of the hydrogel showed no significant differences in mechanical strength of the bone at 4 weeks and histological sections confirmed ongoing healing that was equivalenting the presence or absence of the hydrogel. (d) Increased local tissue (intramedullary extracellular fluid) antibiotic concentrations achieved by the gentamicin-loaded hydrogel compared with gentamicin-loaded bone cement (ALBC) in a sheep model. Images adapted from Ter Boo et al. (2016), Ter Boo et al. (2018) and Vallejo Diaz et al. (2020). 
scaffolds to elicit bone regeneration, without the need to remove them. Compared to the traditional bead-like PMMA spacer, this technology can build patient-specific scaffolds based on medical imaging (computed tomography or MRI) (Fig. 3a). The inclusion of $\mathrm{CaP}$ particles creates pores on the surface of the scaffold, which enable extrinsic or intrinsic cell infiltration (Fig. 3b). Further, the 3D printing process allows for the versatility to incorporate drugs in the form of i) surface- or shell-loading to enable quick, burst release; ii) homogenous loading for prolonged, sustained release; iii) layered loading with multiple drugs for staged release strategies (Fig. 3a). Drug-elution studies found that 3D-printed CaP spacers demonstrate significant improvements in antibiotic release (5-fold) over comparably loaded bone cement spacers (Inzana et al., 2014; Inzana et al., 2015b) (Fig. 3c). Drug elution was further improved by coating $\mathrm{CaP}$ scaffolds with drug-loaded PLGA (Fig. 3d). Finally, in an established murine model of osteomyelitis with DAIR, 3D-printed CaP scaffolds with PLGA coatings outperformed the traditional PMMA cement spacers by significantly reducing the bacterial burden and resulting in more than $50 \%$ complete eradication of the infection (Fig. 3e) (Inzana et al., 2015a; Inzana et al., 2015b; Trombetta et al., 2019a; Trombetta et al., 2021; Trombetta et al., 2019b) (Fig. 3e). Furthermore, bone regeneration was assessed and the 3D-printed scaffolds resulted in a greater than 3-fold increase in bone formation compared with PMMA spacers (Trombetta et al., 2019b). However, this was limited to the bone-scaffold interface and did not result in bridging mineralised callus to result in complete healing. Future goals are to optimise the osteoinductive properties of these scaffolds to eliminate the need to remove them, thereby increasing clinical benefits.

\section{Hydrogel as preventative and therapeutic modality for FRI}

The application of antibiotics directly into surgical sites or infected wounds has remained an area of significant interest in recent years. By applying the antibiotic directly to the infected area, higher concentrations can be achieved compared to systemic administration, without some of the potential adverse effects such as renal toxicity (Hake et al., 2015; Metsemakers et al., 2020a). As already described, ALBC is still commonly applied as cement beads to a trauma wound or as a moulded cement spacer replacing a prosthetic joint, despite significant uncertainty about antibiotic release and efficacy. Currently, several innovative biomaterials are available as promising alternatives to bone cement for local application of antibiotics targeting bone infections (Foster et al., 2020b; Inzana et al., 2016; Ter Boo et al., 2015). These biodegradable materials eliminate the need for follow-up removal surgeries and often have a more optimal and complete antimicrobial release profile (Inzana et al., 2016; McKee et al., 2010). In recent years, Ter Boo et al.
(2016; 2018) have described a degradable thermoresponsive hyaluronic acid hydrogel, loaded with gentamicin, that has outperformed standard singleshot systemic cefuroxime in a rabbit FRI model, without significantly impacting osteotomy healing (Fig. 4). By applying such a gel locally, and not requiring repeated injections, this material displays a significant advantage over conventional systemic antibiotic therapy and has further advantages in terms of wound closure, ease of use and range of potential applications. The hydrogel may also be applied in a pre-hospital setting, as may be done for example by first responders at the scene of an injury. The benefit of this approach is that the material may then be removed during surgery. This approach was tested in a rabbit model and shown to be effective with only a few hours contact time (Vallejo Diaz et al., 2020). More recently, the same hydrogel has been loaded with gentamicin and vancomycin and used in the treatment of a chronic MRSA bone infection in sheep, with performance equivalent to ALBC in successfully eradicating the infection, without the need for later removal of the carrier due to the biodegradable nature of the hydrogel (Boot et al., 2021; Foster et al., 2020a).

\section{Extracorporeal shockwaves}

Focused high-energy ESWT is a treatment modality used to enhance bone healing in fracture non-unions (Everding et al., 2020). ESWT has also been described to have direct anti-bacterial effects (Gerdesmeyer et al., 2005; Horn et al., 2009; Inanmaz et al., 2014; Qi et al., 2016) and increase tissue vascularity (Wang et al., 2003). ESWT was evaluated as an adjunctive treatment alongside conventional surgical debridement and systemic antibiotics in vitro and in a clinically relevant rabbit model of FRI (Arens et al., 2015). After plate fixation of a humeral osteotomy in rabbits, infection was established with a clinical S. aureus isolate. A DAIR procedure was performed after $14 \mathrm{~d}$. Then, rabbits received no further treatment (controls), shockwaves (4,000 impulses, $23 \mathrm{kV}$, at day 2 and 6 after revision), systemic antibiotics (rifampin and nafcillin) or the combination of antibiotics and shockwaves. Treatments were applied over 1 week and euthanasia was performed after another week without treatment to determine infection burden. In this model, the combination of ESWT and systemic antibiotics resulted in an average 100-fold reduction in total CFU compared with antibiotic treatment alone (Puetzler et al., 2020). The reduction in bacteria was the greatest on the implants, which is of special interest as it suggests that shockwaves might facilitate non-invasive in situ eradication of biofilm on foreign bodies and, thus, expand the application range for implant retention. Various mechanisms are currently being discussed. It seems plausible that mechanical stresses (compression, tension and shear), as well as cavitation effects, play a role in direct biofilm disruption (Rassweiler et al., 2011). Electron microscopy images of the implant surface 
show many small craters after ESWT, which are likely caused by microjets created by imploding cavitation bubbles (Milstrey et al., 2021). In addition to direct mechanical effects, mechanotransduction may also play a role. However, to what extent the shock waves induce biochemical signals that elicit specific cellular responses remains to be elucidated.

In the in vivo model, ESWT did not induce dissemination of bacteria into the bloodstream, suggesting that ESWT may not be a risk for bacteraemia, even when given with high energy in case of local, high bacterial loads. Future studies will be required to determine the effect of ESWT on eukaryotic cells at the implant interface as well as longer term in vivo studies.

\section{Diagnosis}

\section{Rapid sensitive detection of pathogens causing bone infection}

To improve the prognosis and provide focused therapy of bone infections, particularly those involving implants, methods for rapid and accurate identification of causative pathogens are highly relevant. With the introduction of MALDI-TOF MS into microbiological diagnostic laboratories about a decade ago, rapid identification of pathogens to the species level from microbial cultures became possible within a few minutes (Bizzini et al., 2011; Borens et al., 2012). For identifying microbial species directly out of liquid culture, MALDI-TOF MS workflows are already regularly used for blood culture specimens [reviewed in Morgenthaler and Kostrzewa (2015) and Ruiz-Aragon et al. (2017)] containing a variable degree of host cellular remnants. This has recently been adapted to joint specimens taken during surgery (Kuo et al., 2020; Noll et al., 2020). In addition, successful identification protocols bypassing a culture step and directly using liquid specimens, such as cerebrospinal fluid (Bishop et al., 2018; Segawa et al., 2014) and urine (Inigo et al., 2016; Li et al., 2019), have been published. In contrast, specimens associated with PJI have only low bacterial densities with concomitant cellular debris so that direct, culture-less bacterial identification out of these specimens is difficult (Lallemand et al., 2016). In those cases, enrichment steps $-e . g$. in liquid medium, prolonged incubation, increase sensitivity and specificity (Font-Vizcarra et al., 2010; Larsen et al., 2012) - are still needed. Also, they allow for observance of slow-growing small colony variants (Bogut et al., 2014) or fastidious bacteria and lead to improved diagnosis (Schafer et al., 2008).

In view of the expected reduction in the time to diagnosis, the use of MALDI-TOF MS for species identification directly from synovial fluid or even host tissues is highly desirable. The most challenging parameters to overcome are the low bacterial load and detritus of human tissue cultures inhibiting the analyses.

\section{Immune proteome studies}

Diagnosis of bone infections remain a primitive art dependent on overt infection symptoms (weeping inflamed wounds) or combinations of direct culture tests and blood-borne biomarkers. Blood-based diagnostics have clear advantages over culture, as they are minimally invasive, less time consuming and easy to administer. Unfortunately, existing diagnostics such as CRP, ESR and WBC are not specific and force clinicians to administer empiric antibiotics until the pathogen is identified in culture (Ricciardi et al., 2020a). To overcome this, the potential of anti-S. aureus antibody levels in serum was investigated (Fig. 5) (Muthukrishnan et al., 2019 b). Among the many immunodominant S. aureus antigens, Morgenstern et al. (2020a) focussed on eight cell-wall-associated or secreted proteins expressed by most virulent strains: cell-wall-modifying enzymes (Amd, Gmd), iron-regulated surface determinant proteins (IsdA, IsdB, and IsdH), toxins and immune evasion proteins (alpha-haemolysin, SCIN, CHIPS). Utilising patient samples from the AO Trauma CPP Bone Infection Registry, which included only S. aureus infected patients [see below for details (Morgenstern et al., 2020a)], it was observed that antibody levels against these antigens rise during infection, providing a blood-based measure of active infection (Kates et al., 2020c). The diagnostic utility of this immunoassay proved to be good (AUC > 0.9) (Nishitani et al., 2015a), which is remarkable considering that most people have appreciable levels of circulating anti-S. aureus antibodies due to its commensal nature. However, serum levels remain elevated for months following an intervention, making serum antibodies poor measures for tracking therapy. To address this limitation, the measurement of circulating ASCs was explored (Fig. 5). ASCs are present in the blood only when an infection is ongoing; upon resolution, their levels drop to 0 . Using these assays developed for serum antibodies to study ASCs, S. aureus-infected patients with multiple types of bone infections, tracked therapy and recurrence were studied (Muthukrishnan et al., 2020; Oh et al., 2018). Additionally, Sulovari et al. (2020) achieved reasonable success in simultaneous identification of Streptococcus agalactiae and S. aureus infections in the same immunoassay. However, a critical high priority area of future research is developing immunodiagnostic assays for reliable identification of polymicrobial infections, including $S$. aureus, $S$. epidermidis, Streptococcus agalactiae, Cutibacterium acnes and Enterobacteriae.

\section{Clinical evidence generation}

\section{AO Trauma Registry}

The AO Trauma CPP Bone Infection Registry was developed to improve the understanding of hostpathogen interaction by collecting clinical data, bacterial isolates and serum from patients with $S$. 
aureus bone infection (Kates et al., 2020a; Morgenstern et al., 2020a). The prospective multinational registry with a 12-month follow-up included adult patients (18 years or older) with culture-confirmed S. aureus infection in long bones after fracture fixation or arthroplasty. Baseline patient attributes and details on infections and treatments were recorded. Blood and serum samples were obtained at baseline, 6 and 12 months. Clinical outcomes and patient-reported outcomes using the Short Form 36 Health Survey Questionnaire (version 2), Parker Mobility Score and Katz Index of Independence in Activities of Daily Living were assessed at 1, 6 and 12 months.

In total, 292 patients were enrolled between November 2012 and August 2017 in 18 centres from 10 countries in Europe, North America, South America and Asia. MRSA was detected in one third of the patients $(n=82,28.4 \%)$. Patients from North America

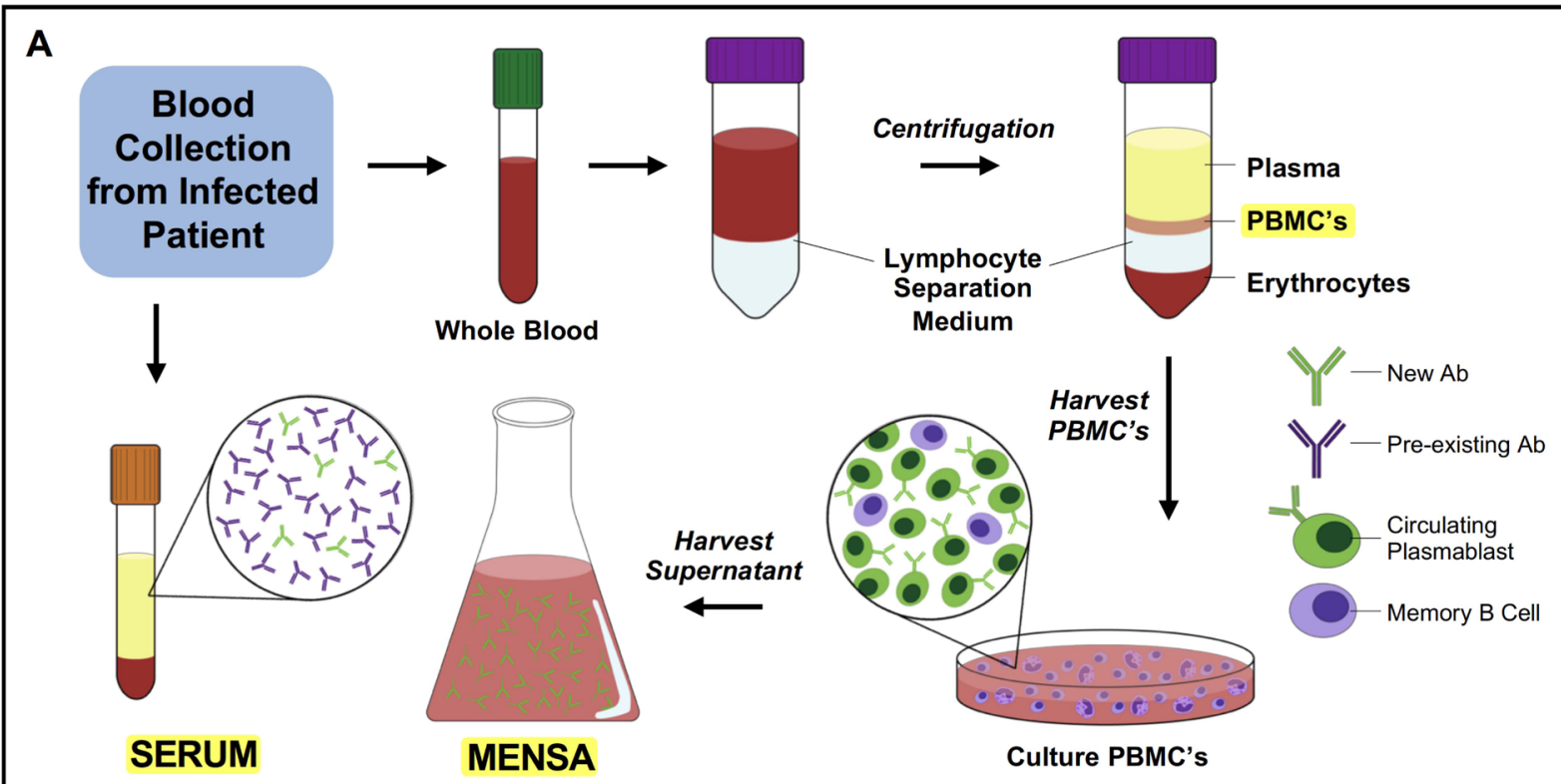

B

S. aureus Negative
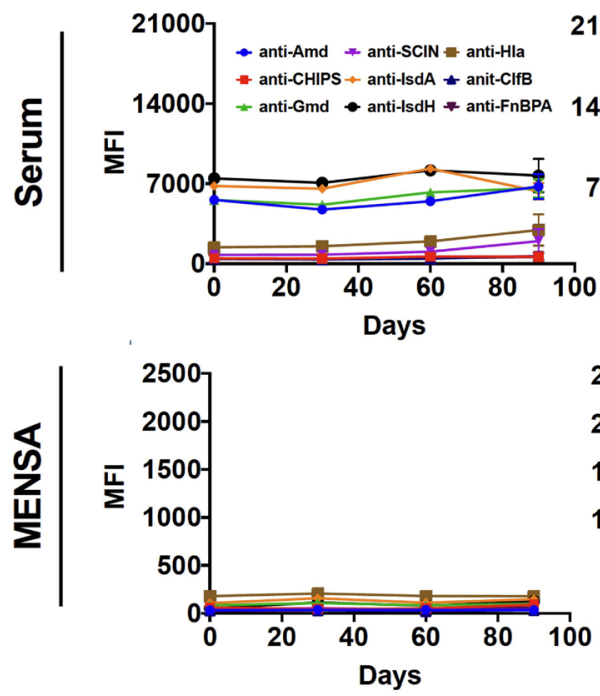

S. aureus Positive Healed
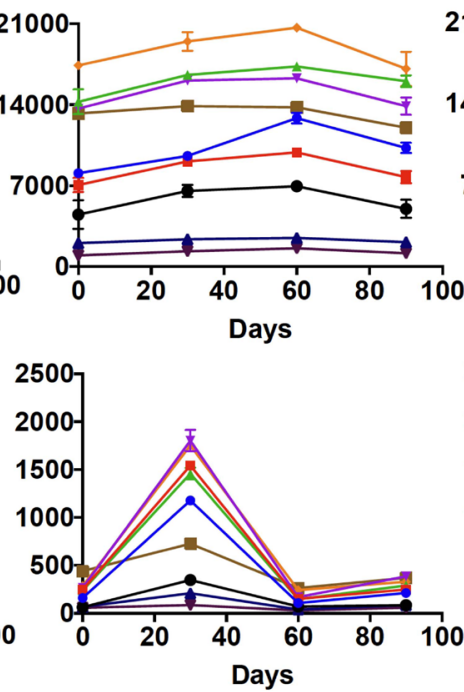

\section{S. aureus Positive Not Healed}
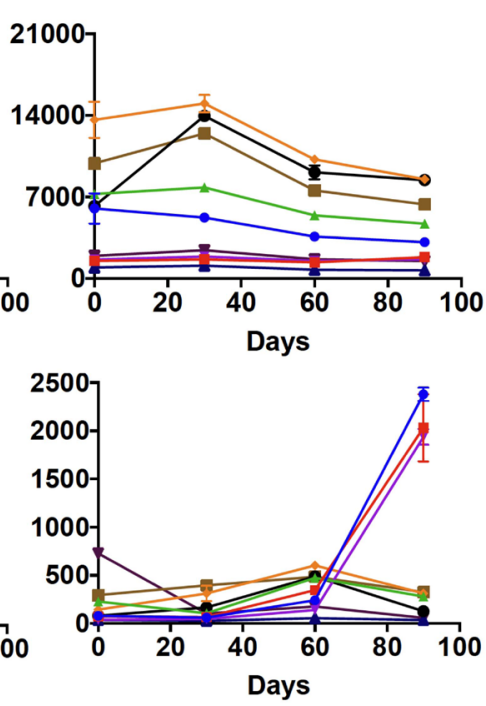

Fig. 5. A diagnostic and prognostic immunoassay for the measurement of anti-S. aureus antibody levels in patients with osteomyelitis. (a) Schematic illustration of production of serum and isolation of MENSA from peripheral mononuclear cells of patients with osteomyelitis. (b) Anti-S. aureus antibody levels in serum and MENSA were determined using a custom bead-based multiantigen Luminex immunoassay developed by the authors. Anti-S. aureus IgG responses were examined in serum and MENSA of DFI patients undergoing FST. The change in antibody titres over the course of FST of a representative patient whose DFI was negative for $S$. aureus, a patient with $S$. aureus infection that responded to FST and a patient with S. aureus DFI that failed FST are presented. Remarkably, MENSA levels faithfully reflected the $S$. aureus infection over time while serum levels remained unchanged (see Oh and Muthukrishnan et al., 2018; Oh et al., 2018). Reproduced with permission from Masters et al. (2019b). 
sites had the highest proportion of MRSA infections $(n=39,48.8 \%)$, patients from Central European sites the lowest $(n=18,12.2 \%)$. An improvement in patient outcomes was found at 6 and 12 months when compared to baseline. Despite an improvement following infection treatment, fewer than two thirds of the patients were cured at the 1-year follow-up (118/194, 62.1\%). Patient-reported outcome scores at the 12-month follow-up were worse for patients with MRSA infections as compared to infections with methicillin-susceptible strains (Morgenstern et al., 2020a). The biospecimens collected with the clinical data will allow for the analysis of relationships between patient demographics, comorbidities, treatment modality, patient-specific host immunity to the causal pathogen(s) and outcomes (Morgenstern et al., 2020a), early examples of which are already published (Lee et al., 2020).

In a prospective point-prevalence study, antibiotic resistance of commensal $S$. aureus and CoNS was investigated in an international cohort of 1,166 surgeons from 75 countries. The average $S$. aureus nasal colonisation rate was $28.0 \%$ and MRSA rate $2.0 \%$. The observed regional variations were significant, with the highest rates of MRSA colonisation in Asia, Africa and Central America and the lowest in North America and Europe. High rates of methicillin-resistant CoNS nasal carriage of $21.4 \%$ were observed with a similar geographic distribution. However, colonisation rates in patients receiving orthopaedic surgery are broadly equivalent to the general population. Recent use of systemic antibiotics was associated with higher rates of carriage of resistant staphylococci (Morgenstern et al., 2016).

\section{Standardised management guidelines for FRI}

Until recently, management principles of FRI were based on research that has primarily been performed on PJI. Although there are similarities, FRIs have unique features (i.e. fracture, bone healing, soft-tissue injury, option to remove implant after healing) that need to be considered (Metsemakers et al., 2018b). A recent literature review confirmed the lack of high-quality scientific evidence in the FRI field and stressed the importance of the development of standardised management guidelines (Bezstarosti et al., 2019). Therefore, the FRI Consensus Group was created under the umbrella of the AO Foundation (i.e. AO Trauma CPP on Bone Infection, Technical Commission's AIGEC, AO Research Institute Davos) in collaboration with well-known international organisations (i.e. EBJIS, OTA, PRO-IMPLANT Foundation). The main aim of this group was to develop standardised principles for diagnosis and treatment based on scientific evidence and expert opinion.

During the first consensus meeting, the experts concluded - based on review of the literature (Metsemakers et al., 2018a) - that although a wellestablished diagnosis is the first step in the treatment process of FRI, standardisation within this field has been poor. The lack of a definition based on diagnostic criteria for infection has hampered the development of treatment protocols that are based on comparable studies and outcomes. For these reasons, an international consensus definition for FRI was developed (Metsemakers et al., 2018c) and recently updated (Govaert et al., 2020). Two levels of certainty around diagnostic features were defined. Criteria for infection can be confirmatory (infection is present) or suggestive. The presence of one of the five confirmatory signs should prompt the initiation of treatment. Suggestive signs should motivate the medical team to further investigate the possibility of the presence of confirmatory signs (Metsemakers et al., 2020b). This definition should not only improve the quality of published reports but also the overall management of these patients in daily clinical practice (Obremskey et al., 2020). Careful attention to establish an adequate diagnosis of FRI allows for better surgical planning and pathogen-specific antimicrobial therapy, leading to an improved patient outcome (McNally et al., 2020). Currently, multiple projects are being finalised to validate this FRI consensus definition, leading to a further improvement in the diagnostic pathway.

As a next step, a second consensus meeting was convened, focussing on management principles in general and assessment of outcome. At the centre of these recommendations was the implementation of a multidisciplinary team approach. This should lead to appropriate use of antimicrobials and standardisation of surgical strategies (Metsemakers et al., 2020b). Two main surgical concepts were described. The first concept consists of implant retention and the second of implant removal (healed fracture) or implant exchange [unhealed fracture (Metsemakers et al., 2020b)]. Furthermore, multiple key aspects for an optimal surgical treatment were presented. One of the cornerstones of every surgical approach being a judicious and well-planned debridement with removal of all dead tissues and acquisition of deep tissue biopsies for microbiology and histopathology. This should be followed by osseous stabilisation (if required), delivery of antimicrobial therapy (using local and systemic antimicrobials) and sufficient vital soft tissue coverage (Depypere et al., 2020b). Guidelines regarding antimicrobial therapy (i.e. local and systemic) were developed and published separately (Depypere et al., 2020a; Metsemakers et al., 2020a). Finally, it was stressed that a minimum follow up of 12 months is critical. This should not only include clinical outcomes of fracture union and absence of infection recurrence but also standardised patient-reported outcome measures (Metsemakers et al., 2020b).

\section{Education}

Because research needs to be disseminated and understood by clinicians and other scientists, it was 
essential to develop a formal education programme on musculoskeletal infection as part of the CPP on Bone Infection. Using a backward-planning process, in conjunction with the $\mathrm{AO}$ Education Institute, the CPP Bone Infection team developed a formal AO infection course which has been offered to the surgical community since 2012. Initially offered in Davos, Switzerland, the course has been given in many regions including Europe, Asia, Latin America and the Middle East. The AO infection course has focused on dissemination of best practices in prevention, diagnosis and treatment of bone infections. Most of the focus has revolved around FRI but there has been limited coverage of PJI as well. The CPP Bone Infection team has also offered educational symposia at many large international scientific meetings including EBJIS, OTA, MSIS, ORS, CORS and others. Overall, the participant ratings at these educational offerings have been high and have reflected the overall need for such in person educational offerings. A textbook, Principles of Orthopedic Infection Management, was also produced by the AO Trauma CPP Bone Infection team and has been well received and widely read.

\section{Future directions}

\section{Training the next generation of bone-infection investigators}

While development of novel diagnostics and interventions for bone infection is the primary goal of the AO Trauma CPP on Bone Infection, it is likely that the greatest impact of this research will be the training of the next generation of scientists, biomedical engineers and surgeons, who must continue this work if it is to improve patient care. As cutting-edge research in this field requires great depth and breadth in microbial pathogenesis, osteoimmunology, surgery, drug-device development, in vivo modelling, regulatory science, clinical trials and cost-effectiveness outcomes, the AO Trauma CPP on Bone Infection has been remarkably successful in recruiting very talented young men and women within these sub-specialties to perform this work during their graduate and post-doctorate training. In additions to their research outcomes and deliverables, the AO Trauma CPP on Bone Infection also mentored dozens of trainees in team-based structured science, scholarship and oral presentation of their work at international meetings. In doing so, these future leaders now have the requisite knowledge, skills, confidence and networks to add onto the accomplishments of their mentors and hopefully solve any remaining and emerging problems in this field. Indeed, several of the initial trainees in the AO Trauma CPP on Bone Infection have already obtained leadership positions in academia, government and industry, which validates this research, education and training approach that should be emulated by other biomedical training programs.

\section{Translation of technologies for bone infection to the clinic: still not an easy path but has COVID-19 changed anything?}

Out of the numerous technologies being described in the scientific literature aimed at preventing or treating bone infection, a huge majority never makes it to clinical application. The obvious clinical need to provide better preventative and therapeutic interventions is to be balanced against the need for prevention of excessive use of antibiotics. However, at the present time, there appears to be a significant regulatory burden on the application of antimicrobial technologies in the orthopaedic trauma field, that has restricted developments from progressing from preclinical to the clinical stage (Moriarty et al., 2014). To claim an anti-infective benefit, the clinical proof of efficacy places an extremely prohibitive high cost on any party innovating in this field. The result is that many surgeons apply off-label home-made solutions such as antibiotic-loaded bone cements fashioned into makeshift implant coatings or antibiotic powders being dosed directly into wounds. The outlook for innovations to make it to the clinic may require a balanced or stepwise approach where new technologies are first proven to be effective in high-risk cases, with subsequent advancement to more general populations once safety and efficacy are established. This has been the case with the development of the COVID-19 vaccines and monoclonal antibody passive immunisations, which went from concepts through FDA-approved emergency use authorisation in less than one year through an unprecedented contemporary partnership between government and industry for the greater good of humanity.

\section{References}

Alba-Loureiro TC, Hirabara SM, Mendonca JR, Curi R, Pithon-Curi TC (2006) Diabetes causes marked changes in function and metabolism of rat neutrophils. J Endocrinol 188: 295-303.

Alonzo F 3rd, Torres VJ (2013) Bacterial survival amidst an immune onslaught: the contribution of the Staphylococcus aureus leukotoxins. PLoS Pathog 9: e1003143. DOI: 10.1371/journal.ppat.1003143.

Alonzo F 3rd, Torres VJ (2014) The bicomponent pore-forming leucocidins of Staphylococcus aureus. Microbiol Mol Biol Rev 78: 199-230.

Arens D, Wilke M, Calabro L, Hackl S, Zeiter S, Zderic I, Richards RG, Moriarty TF (2015) A rabbit humerus model of plating and nailing osteosynthesis with and without Staphylococcus aureus osteomyelitis. Eur Cell Mater 30: 148-161.

Belkaid Y, Hand TW (2014) Role of the microbiota in immunity and inflammation. Cell 157: 121-141.

Bembde AS (2012) A study of plasma fibrinogen level in type-2 diabetes mellitus and its relation to glycemic control. Indian J Hematol Blood Transfus 28: 105-108. 
Beno T, Yoon YJ, Cowin SC, Fritton SP (2006) Estimation of bone permeability using accurate microstructural measurements. J Biomech 39: 23782387.

Bezstarosti H, Van Lieshout EMM, Voskamp LW, Kortram K, Obremskey W, McNally MA, Metsemakers WJ, Verhofstad MHJ (2019) Insights into treatment and outcome of fracture-related infection: a systematic literature review. Arch Orthop Trauma Surg 139: 61-72.

Bishop B, Geffen Y, Plaut A, Kassis O, Bitterman R, Paul M, Neuberger A (2018) The use of matrixassisted laser desorption/ionization time-of-flight mass spectrometry for rapid bacterial identification in patients with smear-positive bacterial meningitis. Clin Microbiol Infect 24: 171-174.

Bizzini A, Jaton K, Romo D, Bille J, Prod'hom G, Greub G (2011) Matrix-assisted laser desorption ionization-time of flight mass spectrometry as an alternative to $16 \mathrm{~S}$ rRNA gene sequencing for identification of difficult-to-identify bacterial strains. J Clin Microbiol 49: 693-696.

Bogut A, Niedzwiadek J, Koziol-Montewka M, Strzelec-Nowak D, Blacha J, Mazurkiewicz T, Marczynski W, Plewik D (2014) Characterization of Staphylococcus epidermidis and Staphyloccocus warneri small-colony variants associated with prosthetic-joint infections. J Med Microbiol 63: 176-185.

Boot W, Schmid T, D'Este M, Guillaume O, Foster A, Decosterd L, Richards RG, Eglin D, Zeiter S, Moriarty TF (2021) A hyaluronic acid hydrogel loaded with gentamicin and vancomycin successfully eradicates chronic methicillin-resistant Staphylococcus aureus orthopedic infection in a sheep model. Antimicrob Agents Chemother 65: e01840-20. DOI: 10.1128/AAC.01840-20.

Borens O, Corvec S, Trampuz A (2012) Diagnosis of periprosthetic joint infections. Hip Int 22 Suppl 8: S9-14.

Brown M, Kowalski R, Zorman J, Wang XM, Towne V, Zhao Q, Secore S, Finnefrock AC, Ebert T, Pancari G, Isett K, Zhang Y, Anderson AS, Montgomery D, Cope L, McNeely T (2009) Selection and characterization of murine monoclonal antibodies to Staphylococcus aureus iron-regulated surface determinant $B$ with functional activity in vitro and in vivo. Clin Vaccine Immunol 16: 1095-1104.

Cardile AP, Sanchez CJ, Jr., Samberg ME, Romano DR, Hardy SK, Wenke JC, Murray CK, Akers KS (2014) Human plasma enhances the expression of Staphylococcal microbial surface components recognizing adhesive matrix molecules promoting biofilm formation and increases antimicrobial tolerance in vitro. BMC Res Notes 7: 457. DOI: 10.1186/1756-0500-7-457.

Castaneda P, McLaren A, Tavaziva G, Overstreet D (2016) Biofilm antimicrobial susceptibility increases with antimicrobial exposure time. Clin Orthop Relat Res 474: 1659-1664.

da Costa TM, de Oliveira CR, Chambers HF, Chatterjee SS (2018) PBP4: a new perspective on Staphylococcus aureus beta-lactam resistance. Microorganisms 6: 57. DOI: 10.3390/ microorganisms6030057.

de Mesy Bentley KL, MacDonald A, Schwarz EM, Oh I (2018) Chronic osteomyelitis with Staphylococcus aureus deformation in submicron canaliculi of osteocytes: a case report. JBJS Case Connect 8: e8. DOI: 10.2106/JBJS.CC.17.00154.

de Mesy Bentley KL, Trombetta R, Nishitani K, Bello-Irizarry SN, Ninomiya M, Zhang L, Chung HL, McGrath JL, Daiss JL, Awad HA (2017) Evidence of Staphylococcus aureus deformation, proliferation, and migration in canaliculi of live cortical bone in murine models of osteomyelitis. J Bone Miner Res 32: 985-990.

Delamaire M, Maugendre D, Moreno M, Le Goff MC, Allannic H, Genetet B (1997) Impaired leucocyte functions in diabetic patients. Diabet Med 14: 29-34.

Depypere M, Kuehl R, Metsemakers WJ, Senneville E, McNally MA, Obremskey WT, Zimmerli W, Atkins BL, Trampuz A, Fracture-Related Infection Consensus G (2020a) Recommendations for systemic antimicrobial therapy in fracture-related infection: a consensus from an international expert group. J Orthop Trauma 34: 30-41.

Depypere M, Morgenstern M, Kuehl R, Senneville E, Moriarty TF, Obremskey WT, Zimmerli W, Trampuz A, Lagrou K, Metsemakers WJ (2020b) Pathogenesis and management of fracture-related infection. Clin Microbiol Infect 26: 572-578.

Dowsey MM, Choong PF (2009) Obese diabetic patients are at substantial risk for deep infection after primary TKA. Clin Orthop Relat Res 467: 1577-1581.

Everding J, Stolberg-Stolberg J, Pützler J, Roßlenbroich S, Ochman S, Raschke M (2020) Extracorporal shock wave therapy for the treatment of arthrodesis non-unions. Arch Orthop Trauma Surg 140: 1191-1200.

Farnsworth CW, Schott EM, Benvie A, Kates SL, Schwarz EM, Gill SR, Zuscik MJ, Mooney RA (2018a) Exacerbated Staphylococcus aureus foot infections in obese/diabetic mice are associated with impaired germinal center reactions, Ig class switching, and humoral immunity. J Immunol 201: 560-572.

Farnsworth CW, Schott EM, Benvie AM, Zukoski J, Kates SL, Schwarz EM, Gill SR, Zuscik MJ, Mooney RA (2018b) Obesity/type 2 diabetes increases inflammation, periosteal reactive bone formation, and osteolysis during Staphylococcus aureus implantassociated bone infection. J Orthop Res 36: 1614-1623.

Farnsworth CW, Schott EM, Jensen SE, Zukoski J, Benvie AM, Refaai MA, Kates SL, Schwarz EM, Zuscik MJ, Gill SR, Mooney RA (2017) Adaptive upregulation of clumping factor A (ClfA) by Staphylococcus aureus in the obese, type 2 diabetic host mediates increased virulence. Infect Immun 85: e01005-16. DOI: 10.1128/IAI.01005-16.

Farnsworth CW, Shehatou CT, Maynard R, Nishitani K, Kates SL, Zuscik MJ, Schwarz EM, Daiss JL, Mooney RA (2015) A humoral immune defect distinguishes the response to Staphylococcus aureus infections in mice with obesity and type 2 diabetes 
from that in mice with type 1 diabetes. Infect Immun 83: 2264-2274.

Font-Vizcarra L, Garcia S, Martinez-Pastor JC, Sierra JM, Soriano A (2010) Blood culture flasks for culturing synovial fluid in prosthetic joint infections. Clin Orthop Relat Res 468: 2238-2243.

Foster AL, Boot W, Stenger V, D'Este M, Jaiprakash A, Eglin D, Zeiter S, Richards RG, Moriarty TF (2020a) Single stage revision of MRSA orthopaedic devicerelated infection in sheep with an antibiotic-loaded hydrogel. J Orthop Res 39: 438-448.

Foster AL, Moriarty TF, Trampuz A, Jaiprakash A, Burch MA, Crawford R, Paterson DL, Metsemakers WJ, Schuetz M, Richards RG (2020b) Fracture-related infection: current methods for prevention and treatment. Expert Rev Anti Infect Ther 18: 307-321.

Foster AL, Moriarty TF, Zalavras C, Morgenstern M, Jaiprakash A, Crawford R, Burch MA, Boot W, Tetsworth K, Miclau T, Ochsner P, Schuetz MA, Richards RG, Metsemakers WJ (2020c) The influence of biomechanical stability on bone healing and fracture-related infection: the legacy of Stephan Perren. Injury 52: 43-52.

Fowler VG, Allen KB, Moreira ED, Moustafa M, Isgro F, Boucher HW, Corey GR, Carmeli Y, Betts R, Hartzel JS, Chan IS, McNeely TB, Kartsonis NA, Guris D, Onorato MT, Smugar SS, DiNubile MJ, Sobanjo-ter Meulen A (2013) Effect of an investigational vaccine for preventing Staphylococcus aureus infections after cardiothoracic surgery: a randomized trial. JAMA 309: 1368-1378.

Gallacher SJ, Thomson G, Fraser WD, Fisher BM, Gemmell CG, MacCuish AC (1995) Neutrophil bactericidal function in diabetes mellitus: evidence for association with blood glucose control. Diabet Med 12: 916-920.

Gerdesmeyer L, von Eiff C, Horn C, Henne M, Roessner M, Diehl P, Gollwitzer H (2005) Antibacterial effects of extracorporeal shock waves. Ultrasound Med Biol 31: 115-119.

Giannoudis PV, Einhorn TA, Marsh D (2007) Fracture healing: the diamond concept. Injury 38 Suppl 4: S3-S6.

Govaert GAM, Kuehl R, Atkins BL, Trampuz A, Morgenstern M, Obremskey WT, Verhofstad MHJ, McNally MA, Metsemakers WJ, FractureRelated Infection Consensus G (2020) Diagnosing fracture-related infection: current concepts and recommendations. J Orthop Trauma 34: 8-17.

Gristina AG (1987) Biomaterial-centered infection: microbial adhesion versus tissue integration. Science 237: 1588-1595.

Gristina AG, Naylor P, Myrvik Q (1988) Infections from biomaterials and implants: a race for the surface. Med Prog Technol 14: 205-224.

Hake ME, Young H, Hak DJ, Stahel PF, Hammerberg EM, Mauffrey C (2015) Local antibiotic therapy strategies in orthopaedic trauma: practical tips and tricks and review of the literature. Injury 46: 1447-1456.
Holmberg A, Rasmussen M (2016) Mature biofilms of Enterococcus faecalis and Enterococcus faecium are highly resistant to antibiotics. Diagn Microbiol Infect Dis 84: 19-21.

Horn C, Mengele K, Gerdesmeyer L, Gradinger R, Gollwitzer H (2009) The effect of antibacterial acting extracorporeal shockwaves on bacterial cell integrity. Med Sci Monit 15: Br364-369.

Inanmaz ME, Uslu M, Isik C, Kaya E, Tas T, Bayram R (2014) Extracorporeal shockwave increases the effectiveness of systemic antibiotic treatment in implant-related chronic osteomyelitis: experimental study in a rat model. J Orthop Res 32: 752-756.

Inigo M, Coello A, Fernandez-Rivas G, Rivaya B, Hidalgo J, Quesada MD, Ausina V (2016) Direct identification of urinary tract pathogens from urine samples, combining urine screening methods and matrix-assisted laser desorption ionization-time of flight mass spectrometry. J Clin Microbiol 54: 988-993.

Inzana JA, Olvera D, Fuller SM, Kelly JP, Graeve OA, Schwarz EM, Kates SL, Awad HA (2014) 3D printing of composite calcium phosphate and collagen scaffolds for bone regeneration. Biomaterials 35: 4026-4034.

Inzana JA, Schwarz EM, Kates SL, Awad HA (2015a) A novel murine model of established Staphylococcal bone infection in the presence of a fracture fixation plate to study therapies utilizing antibiotic-laden spacers after revision surgery. Bone 72: 128-136.

Inzana JA, Schwarz EM, Kates SL, Awad HA (2016) Biomaterials approaches to treating implantassociated osteomyelitis. Biomaterials 81: 58-71.

Inzana JA, Trombetta RP, Schwarz EM, Kates SL, Awad HA (2015b) 3D printed bioceramics for dual antibiotic delivery to treat implant-associated bone infection. Eur Cell Mater 30: 232-247.

Ishikawa F, Yasukawa M, Lyons B, Yoshida S, Miyamoto T, Yoshimoto G, Watanabe T, Akashi K, Shultz LD, Harada M (2005) Development of functional human blood and immune systems in NOD/SCID/IL2 receptor \{gamma\} chain(null) mice. Blood 106: 1565-1573.

Ivy MI, Sharma K, Greenwood-Quaintance KE, Tande AJ, Osmon DR, Berbari EF, Mandrekar J, Beauchamp CP, Hanssen AD, Abdel MP, Lewallen DG, Perry K, Block DR, Snyder MR, Patel R (2021) Synovial fluid $\alpha$ defensin has comparable accuracy to synovial fluid white blood cell count and polymorphonuclear percentage for periprosthetic joint infection diagnosis. Bone Joint J 103-B: 1119-1126.

Jamsen E, Nevalainen P, Eskelinen A, Huotari K, Kalliovalkama J, Moilanen T (2012) Obesity, diabetes, and preoperative hyperglycemia as predictors of periprosthetic joint infection: a single-center analysis of 7181 primary hip and knee replacements for osteoarthritis. J Bone Joint Surg Am 94: e101. DOI: 10.2106/JBJS.J.01935.

Kannel WB, D'Agostino RB, Wilson PW, Belanger AJ, Gagnon DR (1990) Diabetes, fibrinogen, and 
risk of cardiovascular disease: the framingham experience. Am Heart J 120: 672-676.

Kates SL, Hurni S, Chen MS (2020a) Development and challenges in setting up an international bone infection registry. Arch Orthop Trauma Surg 140: 741-749.

Kates SL, Owen JR, Beck CA, Xie C, Muthukrishnan G, Daiss JL, Schwarz EM (2020b) Lack of humoral immunity against glucosaminidase is associated with postoperative complications in Staphylococcus aureus osteomyelitis. J Bone Joint Surg Am 102: 1842-1848.

Kates SL, Owen JR, Beck CA, Xie C, Muthukrishnan G, Daiss JL, Schwarz EM (2020c) Lack of humoral immunity against glucosaminidase is associated with postoperative complications in Staphylococcus aureus osteomyelitis. J Bone Joint Surg Am 102: 1842-1848.

Kim HK, DeDent A, Cheng AG, McAdow M, Bagnoli F, Missiakas DM, Schneewind O (2010) IsdA and IsdB antibodies protect mice against Staphylococcus aureus abscess formation and lethal challenge. Vaccine 28: 6382-6392.

Kuklin NA, Clark DJ, Secore S, Cook J, Cope LD, McNeely T, Noble L, Brown MJ, Zorman JK, Wang XM, Pancari G, Fan H, Isett K, Burgess B, Bryan J, Brownlow M, George H, Meinz M, Liddell ME, Kelly R, Schultz L, Montgomery D, Onishi J, Losada M, Martin M, Ebert T, Tan CY, Schofield TL, Nagy E, Meineke A, Joyce JG, Kurtz MB, Caulfield MJ, Jansen KU, McClements W, Anderson AS (2006) A novel Staphylococcus aureus vaccine: iron surface determinant B induces rapid antibody responses in rhesus macaques and specific increased survival in a murine $S$. aureus sepsis model. Infect Immun 74: 2215-2223.

Kuo FC, Chien CC, Lee MS, Wang JW, Lin PC, Lee CH (2020) Rapid diagnosis of periprosthetic joint infection from synovial fluid in blood culture bottles by direct matrix-assisted laser desorption ionization time-of-flight mass spectrometry. PLoS One 15: e0239290. DOI: 10.1371/journal.pone.0239290.

Kuwabara WMT, Yokota CNF, Curi R, AlbaLoureiro TC (2018) Obesity and type 2 diabetes mellitus induce lipopolysaccharide tolerance in rat neutrophils. Sci Rep 8: 17534. DOI: 10.1038/s41598018-35809-2.

Lallemand E, Coiffier G, Arvieux C, Brillet E, Guggenbuhl P, Jolivet-Gougeon A (2016) MALDI-TOF MS performance compared to direct examination, culture, and 16S rDNA PCR for the rapid diagnosis of bone and joint infections. Eur J Clin Microbiol Infect Dis 35: 857-866.

Lan P, Tonomura N, Shimizu A, Wang S, Yang YG (2006) Reconstitution of a functional human immune system in immunodeficient mice through combined human fetal thymus/liver and CD34+ cell transplantation. Blood 108: 487-492.

Larsen LH, Lange J, Xu Y, Schonheyder HC (2012) Optimizing culture methods for diagnosis of prosthetic joint infections: a summary of modifications and improvements reported since 1995. J Med Microbiol 61: 309-316.
Lee CC, Southgate RD, Jiao C, Gersz E, Owen JR, Kates SL, Beck CA, Xie C, Daiss JL, Post V, Moriarty TF, Zeiter S, Schwarz EM, Muthukrishnan G (2020) Deriving a dose and regimen for antiglucosaminidase antibody passive-immunisation for patients with Staphylococcus aureus osteomyelitis. Eur Cell Mater 39: 96-107.

Li D, Gromov K, Soballe K, Puzas JE, O'Keefe RJ, Awad H, Drissi H, Schwarz EM (2008) Quantitative mouse model of implant-associated osteomyelitis and the kinetics of microbial growth, osteolysis, and humoral immunity. J Orthop Res 26: 96-105.

Li W, Sun E, Wang Y, Pan H, Zhang Y, Li Y, Zhang X, Li C, Du L, Wang C (2019) Rapid identification and antimicrobial susceptibility testing for urinary tract pathogens by direct analysis of urine samples using a MALDI-TOF MS-based combined protocol. Front Microbiol 10: 1182. DOI: 10.3389/fmicb.2019.01182.

Lumeng CN, Saltiel AR (2011) Inflammatory links between obesity and metabolic disease. J Clin Invest 121: 2111-2117.

Marson BA, Deshmukh SR, Grindlay DJC, Scammell BE (2018) Alpha-defensin and the synovasure lateral flow device for the diagnosis of prosthetic joint infection: a systematic review and meta-analysis. Bone Joint J 100-B: 703-711.

Masters EA, de Mesy Bentley KL, Gill AL, Hao SP, Galloway CA, Salminen AT, Guy DR, McGrath JL, Awad HA, Gill SR, Schwarz EM (2020) Identification of penicillin binding protein 4 (PBP4) as a critical factor for Staphylococcus aureus bone invasion during osteomyelitis in mice. PLoS Pathog 16: e1008988. DOI: 10.1371/journal.ppat.1008988.

Masters EA, Salminen AT, Begolo S, Luke EN, Barrett SC, Overby CT, Gill AL, de Mesy Bentley KL, Awad HA, Gill SR, Schwarz EM, McGrath JL (2019a) An in vitro platform for elucidating the molecular genetics of $S$. aureus invasion of the osteocyte lacuno-canalicular network during chronic osteomyelitis. Nanomedicine 21: 102039. DOI: 10.1016/j.nano.2019.102039.

Masters EA, Trombetta RP, de Mesy Bentley KL, Boyce BF, Gill AL, Gill SR, Nishitani K, Ishikawa M, Morita $\mathrm{Y}$, Ito H, Bello-Irizarry SN, Ninomiya M, Brodell JD Jr, Lee CC, Hao SP, Oh I, Xie C, Awad HA, Daiss JL, Owen JR, Kates SL, Schwarz EM, Muthukrishnan G (2019b) Evolving concepts in bone infection: redefining "biofilm", "acute vs. chronic osteomyelitis", "the immune proteome" and "local antibiotic therapy". Bone Res 7: 20. DOI: 10.1038/ s41413-019-0061-z.

McKee MD, Li-Bland EA, Wild LM, Schemitsch EH (2010) A prospective, randomized clinical trial comparing an antibiotic-impregnated bioabsorbable bone substitute with standard antibiotic-impregnated cement beads in the treatment of chronic osteomyelitis and infected nonunion. J Orthop Trauma 24: 483-490.

McNally M, Govaert G, Dudareva M, Morgenstern M, Metsemakers WJ (2020) Definition and diagnosis of fracture-related infection. EFORT Open Rev 5: 614-619. 
Metsemakers WJ, Fragomen AT, Moriarty TF, Morgenstern M, Egol KA, Zalavras C, Obremskey WT, Raschke M, McNally MA, Fracture-Related Infection consensus group (2020a) Evidence-based recommendations for local antimicrobial strategies and dead space management in fracture-related infection. J Orthop Trauma 34: 18-29.

Metsemakers WJ, Kortram K, Morgenstern M, Moriarty TF, Meex I, Kuehl R, Nijs S, Richards RG, Raschke M, Borens O, Kates SL, Zalavras C, Giannoudis PV, Verhofstad MHJ (2018a) Definition of infection after fracture fixation: a systematic review of randomized controlled trials to evaluate current practice. Injury 49: 497-504.

Metsemakers WJ, Kuehl R, Moriarty TF, Richards RG, Verhofstad MHJ, Borens O, Kates S, Morgenstern M (2018b) Infection after fracture fixation: current surgical and microbiological concepts. Injury 49: 511-522.

Metsemakers WJ, Morgenstern M, McNally MA, Moriarty TF, McFadyen I, Scarborough M, Athanasou NA, Ochsner PE, Kuehl R, Raschke M, Borens O, Xie Z, Velkes S, Hungerer S, Kates SL, Zalavras C, Giannoudis PV, Richards RG, Verhofstad MHJ (2018c) Fracture-related infection: a consensus on definition from an international expert group. Injury 49: 505-510.

Metsemakers WJ, Morgenstern M, Senneville E, Borens O, Govaert GAM, Onsea J, Depypere M, Richards RG, Trampuz A, Verhofstad MHJ, Kates SL, Raschke M, McNally MA, Obremskey WT, FractureRelated Infection (FRI) group (2020b) General treatment principles for fracture-related infection: recommendations from an international expert group. Arch Orthop Trauma Surg 140: 1013-1027.

Metsemakers WJ, Reul M, Nijs S (2015) The use of gentamicin-coated nails in complex open tibia fracture and revision cases: a retrospective analysis of a single centre case series and review of the literature. Injury 46: 2433-2437.

Milstrey A, Rosslenbroich S, Everding J, Raschke MJ, Richards RG, Moriarty TF, Puetzler J (2021) Antibiofilm efficacy of focused high-energy extracorporeal shockwaves and antibiotics in vitro. Bone Joint Res 10: 77-84.

Moojen DJ, Hentenaar B, Charles Vogely H, Verbout AJ, Castelein RM, Dhert WJ (2008) In vitro release of antibiotics from commercial PMMA beads and articulating hip spacers. J Arthroplasty 23: 11521156.

Morgenstern M, Erichsen C, Hackl S, Mily J, Militz M, Friederichs J, Hungerer S, Buhren V, Moriarty TF, Post V, Richards RG, Kates SL (2016) Antibiotic resistance of commensal Staphylococcus aureus and coagulase-negative staphylococci in an international cohort of surgeons: a prospective point-prevalence study. PLoS One 11: e0148437. DOI: 10.1371/journal. pone.0148437.

Morgenstern M, Erichsen C, Militz M, Xie Z, Peng J, Stannard J, Metsemakers WJ, Schaefer D, Alt V, Soballe K, Nerlich M, Buckley RE, Blauth M, Suk M, Leung F, Barla JD, Yukata K, Qing B, Kates SL (2020a) The AO Trauma CPP bone infection registry: epidemiology and outcomes of Staphylococcus aureus bone infection. J Orthop Res 39: 136-146.

Morgenstern M, Erichsen C, Militz M, Xie Z, Peng PJ, Stannard J, Metsemakers WJ, Schaefer D, Alt V, Soballe K, Nerlich M, Buckley RE, Blauth M, Suk M, Leung F, Barla JD, Yukata K, Qing B, Kates SL (2020b) The AO Trauma CPP bone infection registry: epidemiology and outcomes of Staphylococcus aureus bone infection. J Orthop Res 39: 136-146.

Morgenthaler NG, Kostrzewa M (2015) Rapid identification of pathogens in positive blood culture of patients with sepsis: review and meta-analysis of the performance of the sepsityper kit. Int J Microbiol 2015: 827416. DOI: $10.1155 / 2015 / 827416$.

Moriarty TF, Grainger DW, Richards RG (2014) Challenges in linking preclinical anti-microbial research strategies with clinical outcomes for deviceassociated infections. Eur Cell Mater 28: 112-128.

Muthukrishnan G, Masters EA, Daiss JL, Schwarz EM (2019a) Mechanisms of immune evasion and bone tissue colonization that make Staphylococcus aureus the primary pathogen in osteomyelitis. Curr Osteoporos Rep 17: 395-404.

Muthukrishnan G, Masters EA, Daiss JL, Schwarz EM (2019b) Mechanisms of immune evasion and bone tissue colonization that make Staphylococcus aureus the primary pathogen in osteomyelitis. Curr Osteoporos Rep 17: 395-404.

Muthukrishnan G, Soin S, Beck CA, Grier A, Brodell JD Jr, Lee CC, Ackert-Bicknell CL, Lee FE, Schwarz EM, Daiss JL (2020) A bioinformatic approach to utilize a patient's antibody-secreting cells against Staphylococcus aureus to detect challenging musculoskeletal infections. Immunohorizons 4: 339351.

Muthukrishnan G, Wallimann A, Rangel-Moreno J, Bentley KLM, Hildebrand M, Mys K, Kenney HM, Sumrall ET, Daiss JL, Zeiter S, Richards RG, Schwarz EM, Moriarty TF (2021) Humanized mice exhibit exacerbated abscess formation and osteolysis during the establishment of implant-associated Staphylococcus aureus osteomyelitis. Front Immunol 12: 651515. DOI: 10.3389/fimmu.2021.651515

Neut D, van de Belt $H$, van Horn JR, van der Mei HC, Busscher HJ (2003) Residual gentamicin-release from antibiotic-loaded polymethylmethacrylate beads after 5 years of implantation. Biomaterials 24: 1829-1831.

Nishitani K, Beck CA, Rosenberg AF, Kates SL, Schwarz EM, Daiss JL (2015a) A diagnostic serum antibody test for patients with Staphylococcus aureus osteomyelitis. Clin Orthop Relat Res 473: 2735-2749.

Nishitani K, Ishikawa M, Morita Y, Yokogawa N, Xie C, de Mesy Bentley KL, Ito H, Kates SL, Daiss JL, Schwarz EM (2020) IsdB antibody-mediated sepsis following $S$. aureus surgical site infection. JCI Insight 5: e141164. DOI: 10.1172/jci.insight.141164.

Nishitani K, Sutipornpalangkul W, de Mesy Bentley KL, Varrone JJ, Bello-Irizarry SN, Ito H, Matsuda S, Kates SL, Daiss JL, Schwarz EM (2015b) 
Quantifying the natural history of biofilm formation in vivo during the establishment of chronic implantassociated Staphylococcus aureus osteomyelitis in mice to identify critical pathogen and host factors. J Orthop Res 33: 1311-1319.

Noll C, Nasruddin-Yekta, A., Sternisek, P., Weig, M., Groß, U., Schilling, A. F., Beil, F. T., Bader, O. (2020) Rapid direct detection of pathogens for diagnosis of joint infections by MALDI-TOF MS after liquid enrichment in the BacT/Alert blood culture system. PLoS One 15: e0243790. DOI: 10.1371/journal. pone.0243790.

Obremskey WT, Metsemakers WJ, Schlatterer DR, Tetsworth K, Egol K, Kates S, McNally M, The ICMOTWG (2020) Musculoskeletal infection in orthopaedic trauma: assessment of the 2018 international consensus meeting on musculoskeletal infection. J Bone Joint Surg Am 102: e44. DOI: 10.2106/ JBJS.19.01070.

Oh I, Muthukrishnan G, Ninomiya MJ, Brodell JD, Jr., Smith BL, Lee CC, Gill SR, Beck CA, Schwarz EM, Daiss JL (2018) Tracking anti-Staphylococcus aureus antibodies produced in vivo and ex vivo during foot salvage therapy for diabetic foot infections reveals prognostic insights and evidence of diversified humoral immunity. Infect Immun 86: DOI: 10.1128/ IAI.00629-18.

Pesch S, Hanschen M, Greve F, Zyskowski M, Seidl F, Kirchhoff C, Biberthaler P, Huber-Wagner S (2020) Treatment of fracture-related infection of the lower extremity with antibiotic-eluting ceramic bone substitutes: case series of 35 patients and literature review. Infection 48: 333-344.

Prabhu VS, Dubberke ER, Dorr MB, Elbasha E, Cossrow N, Jiang Y, Marcella S (2018) Costeffectiveness of bezlotoxumab compared with placebo for the prevention of recurrent clostridium difficile infection. Clin Infect Dis 66: 355-362.

Proctor RA (2015) Recent developments for Staphylococcus aureus vaccines: clinical and basic science challenges. Eur Cell Mater 30: 315-326.

Puetzler J, Milstrey A, Everding J, Raschke M, Arens D, Zeiter S, Geoff Richards R, Fintan Moriarty $\mathrm{T}$ (2020) Focused high-energy extracorporeal shockwaves as supplemental treatment in a rabbit model of fracture-related infection. J Orthop Res 38: 1351-1358.

Qi X, Zhao Y, Zhang J, Han D, Chen C, Huang Y, Chen X, Zhang X, Wang T, Li X (2016) Increased effects of extracorporeal shock waves combined with gentamicin against Staphylococcus aureus biofilms in vitro and in vivo. Ultrasound Med Biol 42: 2245-2252.

Rassweiler JJ, Knoll T, Kohrmann KU, McAteer JA, Lingeman JE, Cleveland RO, Bailey MR, Chaussy C (2011) Shock wave technology and application: an update. Eur Urol 59: 784-796.

Ricciardi BF, Muthukrishnan G, Masters E, Ninomiya M, Lee CC, Schwarz EM (2018) Staphylococcus aureus evasion of host immunity in the setting of prosthetic joint infection: biofilm and beyond. Curr Rev Musculoskelet Med 11: 389-400.
Ricciardi BF, Muthukrishnan G, Masters EA, Kaplan N, Daiss JL, Schwarz EM (2020a) New developments and future challenges in prevention, diagnosis, and treatment of prosthetic joint infection. J Orthop Res 38: 1423-1435.

Ricciardi BF, Muthukrishnan G, Masters EA, Kaplan N, Daiss JL, Schwarz EM (2020b) New developments and future challenges in prevention, diagnosis, and treatment of prosthetic joint infection. J Orthop Res 38: 1423-1435.

Ruiz-Aragon J, Ballestero-Tellez M, GutierrezGutierrez B, de Cueto M, Rodriguez-Bano J, Pascual A (2017) Direct bacterial identification from positive blood cultures using matrix-assisted laser desorption/ ionization time-of-flight (MALDI-TOF) mass spectrometry: a systematic review and meta-analysis. Enferm Infecc Microbiol Clin 36: 484-492.

Sabaté-Brescó M, Berset CM, Zeiter S, Stanic B, Thompson K, Ziegler M, Richards RG, O'Mahony L, Moriarty TF (2021) Fracture biomechanics influence local and systemic immune responses in a murine fracture-related infection model. Biol Open bio.057315. DOI: 10.1242/bio.057315.

Sabaté-Brescó M, Harris LG, Thompson K, Stanic B, Morgenstern M, O'Mahony L, Richards RG, Moriarty TF (2017a) Pathogenic mechanisms and host interactions in Staphylococcus epidermidis device-related infection. Front Microbiol 8: 1401. DOI: 10.3389/fmicb.2017.01401.

Sabaté-Brescó M, O’Mahony L, Zeiter S, Kluge K, Ziegler M, Berset C, Nehrbass D, Richards RG, Moriarty TF (2017b) Influence of fracture stability on Staphylococcus epidermidis and Staphylococcus aureus infection in a murine femoral fracture model. Eur Cell Mater 34: 321-340.

Saeed K, McLaren AC, Schwarz EM, Antoci V, Arnold WV, Chen AF, Clauss M, Esteban J, Gant V, Hendershot E, Hickok N, Higuera CA, Coraca-Huber DC, Choe H, Jennings JA, Joshi M, Li WT, Noble PC, Phillips KS, Pottinger PS, Restrepo C, Rohde H, Schaer TP, Shen H, Smeltzer M, Stoodley P, Webb JCJ, Witso E (2019) 2018 international consensus meeting on musculoskeletal infection: summary from the biofilm workgroup and consensus on biofilm related musculoskeletal infections. J Orthop Res 37: 10071017.

Schafer P, Fink B, Sandow D, Margull A, Berger I, Frommelt L (2008) Prolonged bacterial culture to identify late periprosthetic joint infection: a promising strategy. Clin Infect Dis 47: 1403-1409.

Schwarz EM, McLaren AC, Sculco TP, Brause B, Bostrom M, Kates SL, Parvizi J, Alt V, Arnold WV, Carli A, Chen AF, Choe H, Coraca-Huber DC, Cross M, Ghert M, Hickok N, Amber Jennings J, Joshi M, Metsemakers WJ, Ninomiya M, Nishitani K, Oh I, Padgett D, Ricciardi B, Saeed K, Sendi P, Springer B, Stoodley P, Wenke JC (2020) Adjuvant antibioticloaded bone cement: concerns with current use and research to make it work. J Orthop Res 39: 227-239.

Schwarz EM, Parvizi J, Gehrke T, Aiyer A, Battenberg A, Brown SA, Callaghan JJ, Citak M, Egol 
K, Garrigues GE, Ghert M, Goswami K, Green A, Hammound S, Kates SL, McLaren AC, Mont MA, Namdari S, Obremskey WT, O'Toole R, Raikin S, Restrepo C, Ricciardi B, Saeed K, Sanchez-Sotelo J, Shohat N, Tan T, Thirukumaran CP, Winters B (2019) 2018 International consensus meeting on musculoskeletal infection: research priorities from the general assembly questions. J Orthop Res 37: 997-1006.

Segawa S, Sawai S, Murata S, Nishimura M, Beppu M, Sogawa K, Watanabe M, Satoh M, Matsutani T, Kobayashi M, Iwadate Y, Kuwabara S, Saeki N, Nomura F (2014) Direct application of MALDI-TOF mass spectrometry to cerebrospinal fluid for rapid pathogen identification in a patient with bacterial meningitis. Clin Chim Acta 435: 59-61.

Shiels SM, Mangum LH, Wenke JC (2020) Revisiting the "race for the surface" in a pre-clinical model of implant infection. Eur Cell Mater 39: 77-95.

Shultz LD, Lyons BL, Burzenski LM, Gott B, Chen X, Chaleff S, Kotb M, Gillies SD, King M, Mangada J, Greiner DL, Handgretinger R (2005) Human lymphoid and myeloid cell development in NOD/ LtSz-scid IL2R gamma null mice engrafted with mobilized human hemopoietic stem cells. J Immunol 174: 6477-6489.

Sulovari A, Ninomiya MJ, Beck CA, Ricciardi BF, Ketonis C, Mesfin A, Kaplan NB, Soin SP, McDowell SM, Mahmood B, Daiss JL, Schwarz EM, Oh I (2020) Clinical utilization of species-specific immunoassays for identification of Staphylococcus aureus and Streptococcus agalactiae in orthopedic infections. J Orthop Res. DOI: 10.1002/jor.24935.

Ter Boo GA, Arens D, Metsemakers WJ, Zeiter S, Richards RG, Grijpma DW, Eglin D, Moriarty TF (2016) Injectable gentamicin-loaded thermoresponsive hyaluronic acid derivative prevents infection in a rabbit model. Acta Biomater 43: 185-194.

Ter Boo GJ, Grijpma DW, Moriarty TF, Richards RG, Eglin D (2015) Antimicrobial delivery systems for local infection prophylaxis in orthopedic- and trauma surgery. Biomaterials 52: 113-125.

Ter Boo GJ, Schmid T, Zderic I, Nehrbass D, Camenisch K, Richards RG, Grijpma DW, Moriarty TF, Eglin D (2018) Local application of a gentamicin-loaded thermo-responsive hydrogel allows for fracture healing upon clearance of a high Staphylococcus aureus load in a rabbit model. Eur Cell Mater 35: 151-164.

Thingholm LB, Ruhlemann MC, Koch M, Fuqua B, Laucke G, Boehm R, Bang C, Franzosa EA, Hubenthal M, Rahnavard A, Frost F, Lloyd-Price J, Schirmer M, Lusis AJ, Vulpe CD, Lerch MM, Homuth G, Kacprowski T, Schmidt CO, Nothlings U, Karlsen TH, Lieb W, Laudes M, Franke A, Huttenhower C (2019) Obese individuals with and without type 2 diabetes show different gut microbial functional capacity and composition. Cell Host Microbe 26: 252-264.

Tiede-Lewis LM, Xie Y, Hulbert MA, Campos R, Dallas MR, Dusevich V, Bonewald LF, Dallas SL (2017) Degeneration of the osteocyte network in the
C57BL/6 mouse model of aging. Aging (Albany NY) 9: 2190-2208.

Torres VJ, Pishchany G, Humayun M, Schneewind O, Skaar EP (2006) Staphylococcus aureus IsdB is a hemoglobin receptor required for heme iron utilization. J Bacteriol 188: 8421-8429.

Tosounidis TH, Calori GM, Giannoudis PV (2016) The use of reamer-irrigator-aspirator in the management of long bone osteomyelitis: an update. Eur J Trauma Emerg Surg 42: 417-423.

Trombetta R, Inzana JA, Schwarz EM, Kates SL, Awad HA (2017) 3D printing of calcium phosphate ceramics for bone tissue engineering and drug delivery. Ann Biomed Eng 45: 23-44.

Trombetta RP, de Mesy Bentley KL, Schwarz EM, Kate SL, Awad HA (2019a) A murine femoral ostectomy model with hardware exchange to assess antibiotic-impregnated spacers for implantassociated osteomyelitis. Eur Cell Mater 37: 431-443.

Trombetta RP, Knapp EK, Awad HA (2021) A mouse femoral ostectomy model to assess bone graft substitutes. Methods Mol Biol 2230: 75-89.

Trombetta RP, Ninomiya MJ, El-Atawneh IM, Knapp EK, de Mesy Bentley KL, Dunman PM, Schwarz EM, Kates SL, Awad HA (2019b) Calcium phosphate spacers for the local delivery of sitafloxacin and rifampin to treat orthopedic infections: efficacy and proof of concept in a mouse model of single-stage revision of device-associated osteomyelitis. Pharmaceutics 11: 94. DOI: 10.3390/ pharmaceutics11020094.

Vallejo Diaz A, Deimling C, Morgenstern M, D’Este M, Puetzler J, Zeiter S, Arens D, Metsemakers WJ, Richards RG, Eglin D, Moriarty TF (2020) Local application of a gentamicin-loaded hydrogel early after injury is superior to perioperative systemic prophylaxis in a rabbit open fracture model. J Orthop Trauma 34: 231-237.

Varrone JJ, de Mesy Bentley KL, Bello-Irizarry SN, Nishitani K, Mack S, Hunter JG, Kates SL, Daiss JL, Schwarz EM (2014) Passive immunization with anti-glucosaminidase monoclonal antibodies protects mice from implant-associated osteomyelitis by mediating opsonophagocytosis of Staphylococcus aureus megaclusters. J Orthop Res 32: 1389-1396.

Wang CJ, Wang FS, Yang KD, Weng LH, Hsu CC, Huang CS, Yang LC (2003) Shock wave therapy induces neovascularization at the tendon-bone junction. A study in rabbits. J Orthop Res 21: 984-989.

Wilcox MH, Gerding DN, Poxton IR, Kelly C, Nathan R, Birch T, Cornely OA, Rahav G, Bouza E, Lee C, Jenkin G, Jensen W, Kim YS, Yoshida J, Gabryelski L, Pedley A, Eves K, Tipping R, Guris D, Kartsonis N, Dorr MB, Modify I, Investigators MI (2017) Bezlotoxumab for prevention of recurrent clostridium difficile infection. N Engl J Med 376: 305317.

Wu C, Qu X, Liu F, Li H, Mao Y, Zhu Z (2014) Risk factors for periprosthetic joint infection after total hip arthroplasty and total knee arthroplasty in Chinese 
patients. PLoS One 9: e95300. DOI: 10.1371/journal. pone.0095300.

Yang D, Wijenayaka AR, Solomon LB, Pederson SM, Findlay DM, Kidd SP, Atkins GJ (2018) Novel insights into Staphylococcus aureus deep bone infections: the involvement of osteocytes. mBio 9: e00415-18. DOI: 10.1128/mBio.00415-18.

Yokogawa N, Ishikawa M, Nishitani K, Beck CA, Tsuchiya H, Mesfin A, Kates SL, Daiss JL, Xie C, Schwarz EM (2018) Immunotherapy synergizes with debridement and antibiotic therapy in a murine 1-stage exchange model of MRSA implant-associated osteomyelitis. J Orthop Res 36: 1590-1598.

Zoller SD, Hegde V, Burke ZDC, Park HY, Ishmael CR, Blumstein GW, Sheppard W, Hamad C, Loftin AH, Johansen DO, Smith RA, Sprague MM, Hori KR, Clarkson SJ, Borthwell R, Simon SI, Miller JF, Nelson SD, Bernthal NM (2020) Evading the host response: Staphylococcus "hiding" in cortical bone canalicular system causes increased bacterial burden. Bone Res 8: 43. DOI: 10.1038/s41413-020-00118-w.

\section{Discussion with Reviewers}

Reviewer: The authors have provided a strong account of the scientific endeavour of their programme aimed at better understanding and treating bone infections. One wonders if it will be equally important to demonstrate to governments and health systems the huge socioeconomic costs of these infections to elevate bone infection to a clinical priority.

Authors: We are fully in agreement with the comment of the reviewer. Demonstration of the huge socioeconomic costs of bone infections, or differently stated, demonstration of the potential of cost savings is something that should be addressed in future research projects within the CPP Bone Infection. This requires cross disciplinary expertise and long term follow-up to fully measure the impact of bone infection. This is not a simple undertaking but would provide the needed justification for continued research and development to address this clinical problem.

Reviewer: Passive immunisation as an approach to protect against $S$. aureus infections appears to be a viable option, as opposed to an active vaccine. It would seem to circumvent the problems of host immune variability, immunosuppression and rapid post-infection phenotypic adaptation by the pathogen. What are the barriers to the implementation of this approach?

Authors: While passive immunisation has the ability to overcome host immunity shortcomings including variability, immunosuppression and a lengthy process to develop protection, it has four major limitations compared to active vaccination that need to be considered. The first is the lack of robustness, as passive immunisation is limited to the monoclonal antibodies that are administered to the patient. Thus, antibodies against other antigens and all forms of cellular immunity are not included in this treatment. The second is the lack of durability, as efficacy from passive immunisation is limited to the 4-8 month half-life of the antibody, while active vaccination has life-long protection potential in some cases. The third is that passive immunisations are 25-50 times more expensive than active vaccines. Using the current COVID-19 examples, the mRNA lipid nanoparticle vaccines (BNT162 and MRNA1273) cost 15-20 USD per dose (Web ref. 1, Web ref. 2) and the passive immunisation (casirivimab and imdevimab) costs 66 USD per dose (Web ref. 3). Using non-pandemic examples, the FDA-approved active vaccine for herpes zoster (Shingrix) costs 155 USD per dose (Web ref. 4 ) and the passive immunisation for Clostridioides difficile (bezlotoxumab) costs 3,976.70 USD per dose (Web ref. 5). Fourth, passive immunisations are delivered intravenously in infusion centers, which presents major challenges for rural communities and 3rd world countries. Therefore, taken together, passive immunisation is broadly considered a therapy to treat active infectious disease, and not a prophylaxis such as active vaccination.

Reviewer: Chemical modification of metal alloys or coatings (e.g. silver) has been an area of intense interest. Are these being considered by the $\mathrm{AO}$ Trauma CPP?

Authors: At the present time, the AO Trauma CPP does not have a surface-coating technology in preclinical research that is targeted for translation.

Reviewer: A number of other approaches to combat orthopaedic-related infections include surface modification, such as creating nano-structures to either release antibiotics or physically kill bacteria; would you have concerns about surface integrity of the modified implants?

Authors: One of the primary concerns in developing a surface coating for an orthopaedic implant is indeed the surface integrity of the implant after sometimes forceful insertion into the patient. In addition to the implant surface integrity, also the integration of the implant with the local tissues is important, particularly the bone: implant interface in arthroplasty. Despite the large number of surface coatings or other surface modifications designed to impart antimicrobial functionality on orthopaedic devices, the application in the clinic is minimal. This is a result of a combination of simple economics on the commercialisation side and the burden for evidence of efficacy and safety on the regulatory side. This is a topic that has run for many years and it seems we are not lacking in the scientific ingenuity to address the problem but the practical route toward clinical application is the main barrier.

Sebastian Zaat: What is the time span required between blood samples' collections to unequivocally assess a rise in the antibody levels against the chosen 
S. aureus antigens? Is this time span sufficiently short to make the technique feasible for a relevant clinical diagnosis?

Authors: These are intriguing questions that frame two of the fundamental under-addressed issues in orthopaedic infections. The first question asks whether measuring increases in antibody titres against $S$. aureus antigens can be used as a tool for clinical diagnosis. When we began this work in 2013, we too were concerned about this same issue. Specifically, every adult human has been infected with $S$. aureus sufficiently to elicit a substantial humoral response that, then, provides a varied and problematic background against which the response to an ongoing infection must be measured.

Our initial assumption was that made by many other investigators: the pre-existing antibody response is sufficiently high and varied that it would obscure the production of new antibodies, thereby making the antibody-based diagnosis of an ongoing infection impossible. To our surprise, this idea turned out to be largely false. As Nishitani et al. (2015) showed, patients bearing different types of orthopaedic infections tended to have elevated antibody titres compared to healthy controls. The antibody-based test was not perfect, but it was as good as many tests are during their initial evaluations. The AUC value in a receiver, operating characteristic curve comparing patients with confirmed $S$. aureus infections to healthy controls, was 0.9 . To be clear, this level of performance required a single sample and no comparison of paired early and late samples, although that could lead to potential improvement.

Our patient population has been heterogeneous, some with initial infections a few weeks post-surgery and others having experienced serial infections, so timing of the intervals between infection, symptom onset and elevation of serum antibody levels has been difficult to measure directly. In the mouse transtibial pin model, Li et al. (2008) showed that the anti-S. aureus IgM serum response was measurable by day 6 post-primary infection and the IgG response by day 11 (although this may be slightly artificial because of the relatively high initial dose of $S$. aureus bacteria on the infection pin). That said, in humans, most primary viral and bacterial infections are detectable by serum antibodies 7-10 d post symptom onset (Carter et al., 2017, additional reference). Considering that anti-S. aureus humoral responses are essentially always secondary responses, this same $7-10 \mathrm{~d}$ estimate is probably conservative. Consequently, with some modest improvements, the serum-based anti-S. aureus immune response is readily measurable in most patients sufficiently early to be comparable or superior to the complicated methods currently recommended (Glaudemans et al., 2019, additional reference) for detection of a new $S$. aureus infection.

We have sought an improved method for detecting and tracking the success of therapy for orthopaedic $S$. aureus infection. How can we measure ongoing infections in "real time"? How can we measure an ongoing infection in such a way that we are not confounded by prior infections? How can we measure the success (or failure) of therapeutic interventions? How can we diagnose recurrences that occur shortly after an initial infection? To address these questions, we introduced the measurement of antibodies secreted by newly stimulated circulating ASCs. ASCs are stimulated in the bone marrow during an ongoing infection and mature into the circulation into plasma cells that either relocate to the bone marrow, where they become long-lived plasma cells, or produce antibody for days to weeks and then die. As a population, ASCs 1) emerge into the circulation prior to sero-conversion, 2) are the cells that will produce the serum antibody response, 3 ) are present in the circulation only during active infection (background is 0). These attributes make them attractive biomarkers for both detecting and tracking therapy of ongoing infections. Briefly, ASCs provide a good measure of nascent infections, although, surprisingly, the AUC values have been slightly lower than those for serum. In addition, ASC levels decline almost to baseline (0) following successful therapy and they rapidly re-emerge upon re-infection (Oh et al., 2018; Muthukrishnan et al., 2020).

Sebastian Zaat: Has the final bone regeneration in the presence of biodegrading 3D-printed spacers that are not removed been assessed? Isn't it necessary at some point when infection has been eradicated to remove the degrading material since it may compromise optimal bone repair?

Authors: We have assessed bone regeneration. In general, the 3D-printed scaffolds resulted in more than 3-fold increase in bone formation compared with PMMA spacers (Trombetta et al., 2019b). However, this was limited to the bone-scaffold interface and did not result in bridging mineralised callus to result in complete healing. Our intention is to optimise the osteo-inductive properties of these scaffolds to eliminate the need to remove them, as suggested by the Reviewer.

\section{Additional References}

CarterMJ, Mitchell RM, Meyer Sauteur PM, Kelly DF, Trück J (2017) The antibody-secreting cell response to infection: kinetics and clinical applications. Front Immunol 8: 630. DOI: 10.3389/ fimmu.2017.00630.

Glaudemans AWJM, Jutte PC, Cataldo MA, Cassar-Pullicino V, Gheysens O, Borens O, Trampuz A, Wörtler K, Petrosillo N, Winkler H, Signore A, Sconfienza LM (2019) Consensus document for the diagnosis of peripheral bone infection in adults: a joint paper by the EANM, EBJIS, and ESR (with ESCMID endorsement). Eur J Nucl Med Mol Imaging 46: 957-970. 


\section{Web References}

1. https://www.pfizer.com/news/press-release/ press-release-detail/pfizer-and-biontech-announceagreement-us-government-600 [07.10.2021]

2. https://www.fiercepharma.com/pharma/afternearly-1b-research-funding-moderna-takes-1-5bcoronavirus-vaccine-order-from-u-s [07.10.2021]

3. https://www.cnbc.com/2020/07/07/regeneronsigns-450-million-contract-with-the-us-governmentfor-its-coronavirus-therapy.html [07.10.2021]
4. ht t p s://ww w.good rx.com/ shingrix?gclid=EAIaIQobChMIpYT-uIX77QIVFovI Ch3ssQLmEAAYAiAAEgLoWvD_BwE [07.10.2021]

5. https://www.drugs.com/price-guide/zinplava [07.10.2021]

Editor's note: The Guest Editor responsible for this paper was Henny Van der Mei. 